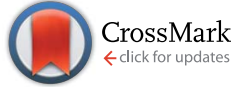

Cite this: RSC Adv., 2016, 6, 19531

Received 20th January 2016 Accepted 9th February 2016

DOI: $10.1039 / c 6 r a 01730 d$

www.rsc.org/advances

\section{Synthesis, structure and coordination properties of novel bifunctional carboxylic derivatives of 1,3- alternate tetrathiacalix[4]arene $\uparrow$}

\author{
Sergey N. Podyachev, ${ }^{* a}$ Gulnaz Sh. Gimazetdinova, ${ }^{\mathrm{b}}$ Aidar T. Gubaidullin, ${ }^{a}$ \\ Victor V. Syakaev, ${ }^{a}$ Svetlana N. Sudakova, ${ }^{a}$ Bulat M. Gabidullin, ${ }^{a}$ Vladimir T. Ivanov, ${ }^{a}$ \\ Edward L. Gogolashvilia and Alexander I. Konovalov ${ }^{a}$
}

\begin{abstract}
New bifunctional derivatives of 1,3-alternate tetrathiacalix[4]arene decorated with carboxylic, ester, hydrazide and/or hydrazone groups have been synthesized with good yields using the tetrathiacalix[4] arene derivatives with incorporated pairs of carboxylic and ester groups as versatile building blocks. The structural peculiarities of the obtained bifunctional compounds have been investigated by means of $X$ ray analysis, IR and NMR spectroscopy. The recognition ability of the synthesized macrocycles towards some alkali, alkali-earth and transition metal ions has been investigated applying a solvent extraction method. The results showed that the structure of a calix[4]arene platform as well as the nature of functional substitutes located on opposite sides of the macrocycle are critical for the coordination properties of the synthesized compounds.
\end{abstract}

\section{Introduction}

The design and synthesis of artificial receptors for cation and anion guests is an exciting topic of current chemistry because of the extreme importance of these compounds for coordination and supramolecular chemistry as well as for biological processes involving molecular recognition of cationic, anionic and neutral species. ${ }^{1-7}$ The sensing properties of the receptors are usually based on their ability to form multiple-point binding sites during interaction with a variety of substrates. It is wellknown that macrocyclic compounds with several donor centers can reveal a unique selectivity towards some substrates. However, there are some restrictive factors on the way of preparing such type of receptors and they are connected not only with an accurate simulation of the structure or prediction the recognition properties of these compounds but obviously deal with the problem of their further synthesis. In many cases, the solving of this problem opens new possibilities to the successful construction of artificial receptors. At the same time, current industrial needs require more and more advanced compounds possessing unique properties and enabling the

${ }^{a}$ A. E. Arbuzov Institute of Organic and Physical Chemistry, Kazan Scientific Center of Russian Academy of Sciences, Arbuzov str., 8, 420088, Kazan, Russia. E-mail: spodyachev@iopc.ru; Fax: +7-843-273-1872

${ }^{b}$ Kazan National Research Technological University, K. Marks str., 68, 420015, Kazan, Russia

$\dagger$ Electronic supplementary information (ESI) available. CCDC 1437363-1437367. For ESI and crystallographic data in CIF or other electronic format see DOI: 10.1039/c6ra01730d progress in the creation of novel functional materials. Therefore, a search for rational approaches to the synthesis of ligands with a desired set of properties is an actual task.

One of the strategies for the molecular design of ligands can be founded on the molecular LEGO approach. It assumes that even a trivial combination of the basic molecular platforms and functional building blocks makes possible to obtain a great number of various sophisticated structures with desired and predictable properties, applying, as a rule, relatively simple chemical protocols. The calix $[n]$ arenes are known as a synthetically and commercially accessible class of compounds which can be successfully applied for these purposes due to their suitable molecular scaffolds. ${ }^{8,9} \mathrm{~A}$ distinctive feature of this class of macrocyclic compounds is their three-dimensional spatially preorganized structure that can be fixed in various isomeric forms. Moreover, such compounds give an opportunity for incorporating of a variety of substitutes both at the upper and lower rims. These peculiarities of calix[4]arenes provide their application as keystones for the creation of bifunctional receptors having unequal binding centers. ${ }^{10-12}$ A possibility of coordinating at least two types of substrates simultaneously extends an application area of these compounds. An interest to such type of calix[4]arene derivatives can be also explained by the fact that they can reveal the biomimetic properties. ${ }^{13}$ Additionally, a presence of spatially divided binding and reaction sites in the structure of the compounds gives an excellent opportunity for the preparation on their base the polymeric as well as covalently fixed on a hard substrate sensing materials.

Among calix $n]$ arene family compounds, the tetrathiacalix[4] arenes attract a special attention. In opposite to their classical 
analogues, they can be easily fixed in any of cone, partial cone or 1,3-alternate isomer forms by using a template effect of metal cations just on the initial stage of their functionalizing. Although the cone-isomers usually reveal substantially higher binding efficiency towards different ions in comparison with 1,3-alternate isomers, the latter are interesting due to their enhanced binding selectivity. ${ }^{\mathbf{1 4 , 1 5}}$ Furthermore, the 1,3-alternate tetrathiacalix[4]arenes can be considered as very suitable tectons for the construction of artificial heteroditopic receptors capable of exhibiting a mimic allosteric binding that plays a major role in biological systems. ${ }^{11,12,16,17}$

In present work we demonstrate a synthetic strategy for the preparing of novel 1,3-alternate tetrathiacalix[4]arene derivatives functionalized by pairs of carboxylic, ester, hydrazide, chloroanhydride as well as hydrazone groups and report the details of the synthesis and spectroscopic characterizations of these compounds. Their structural peculiarities have been investigated by means of X-ray analysis. The receptor properties of the synthesized bifunctional derivatives against alkali, alkaliearth and transition metals were studied by liquid-liquid extraction method and are discussed below.

\section{Results and discussion}

\subsection{Synthesis}

The compounds with ester and carboxylic groups often serve as starting compounds for a further synthesis of a wide range of organic compounds. Therefore, the calix[4]arene scaffolds functionalized by both these groups can be potentially used as promising building blocks for the obtaining of bifunctional macrocyclic derivatives due to the different reactivity of ester and carboxylic groups. ${ }^{18,19}$ The synthetic route utilized by us for the preparation of bifunctional compounds is presented in Fig. 1. The synthesis starts from the parent tetrathiacalix[4] arenes $\mathbf{1 a}$ and $\mathbf{1 b}$ which are converted into the corresponding tetraethyl esters $\mathbf{2 a}$ and $\mathbf{2 b}$ after their alkylation with ethyl bromoacetate in the refluxing acetone and using $\mathrm{Cs}_{2} \mathrm{CO}_{3}$ as a base..$^{20,21}$

1,3-Alternate tetrathiacalix[4]arenes are known to bind $\mathrm{Cs}^{+}$ ions only by "one side" of the macrocycle. This selectivity is obviously caused by the allosteric effect. ${ }^{22,23}$ Taking this fact into account, we have developed an effective protocol for the synthesis of dicarboxylic tetrathiacalix[4] arene derivatives $3 \mathbf{a}$ and $\mathbf{3 b}$. The reflux of the compounds $\mathbf{2 a}$ and $\mathbf{2} \mathbf{b}$ in the THF solution containing 5 vol\% of water and 12 equivalents of $\mathrm{Cs}_{2} \mathrm{CO}_{3}$ resulted in the formation of cesium salts of $\mathbf{3 a}$ and $\mathbf{3 b}$, respectively. After treatment of the precipitates with $\mathrm{HCl}$, the calix[4]arenes $\mathbf{3 a}$ and $\mathbf{3} \mathbf{b}$ were obtained with good yields. The details of the synthetic procedure and the supposed mechanism of the reaction as well as the structures of the compounds $\mathbf{3 a}, \mathbf{3} \mathbf{b}$ and dicesium salt of $\mathbf{3 a}$ determined by the X-ray analysis have been reported recently. ${ }^{24}$

The obtained compounds $\mathbf{3 a}$ and $\mathbf{3 b}$ can undergo a further selective transformation on both sides of the tetrathiacalix[4] arene platform. We were especially interested in the introduction of hydrazide groups into the macrocyclic framework. According

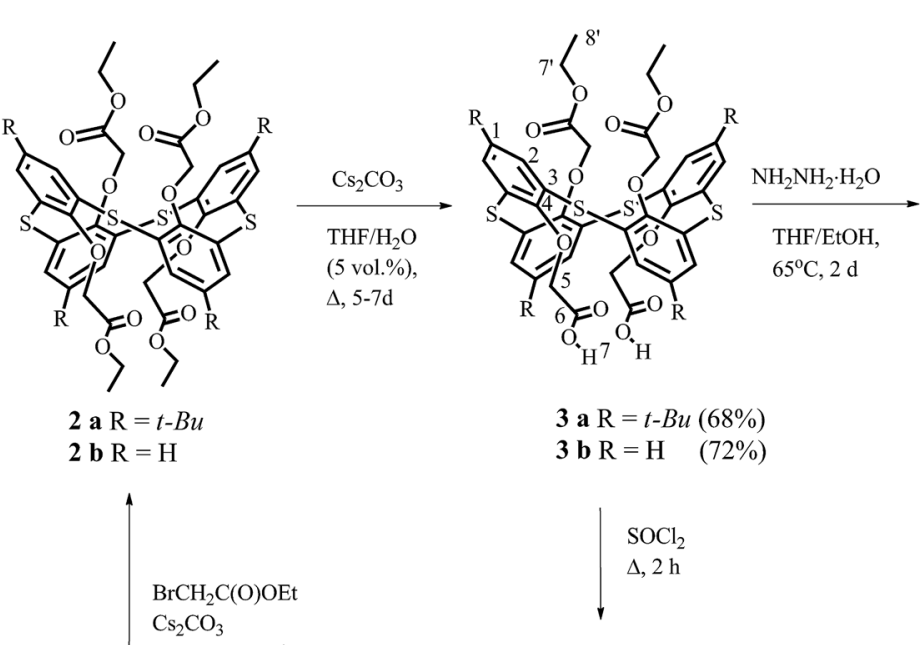

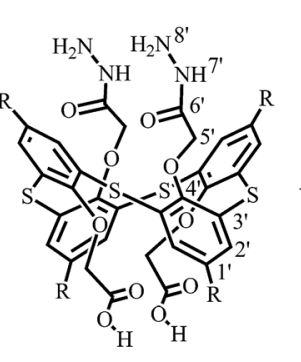

4 a $\mathrm{R}=t-B u(92 \%)$

4 b $\mathrm{R}=\mathrm{H} \quad(85 \%)$

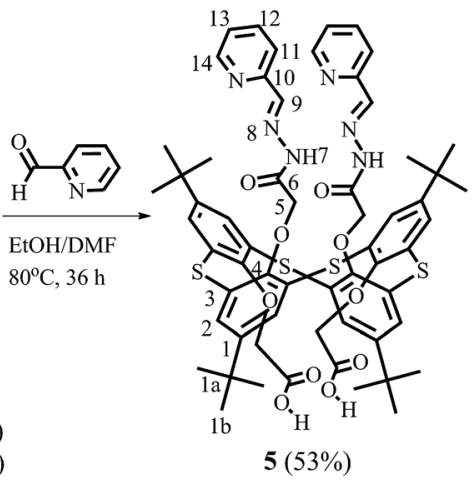

acetone, $\Delta, 5 \mathrm{~d}$
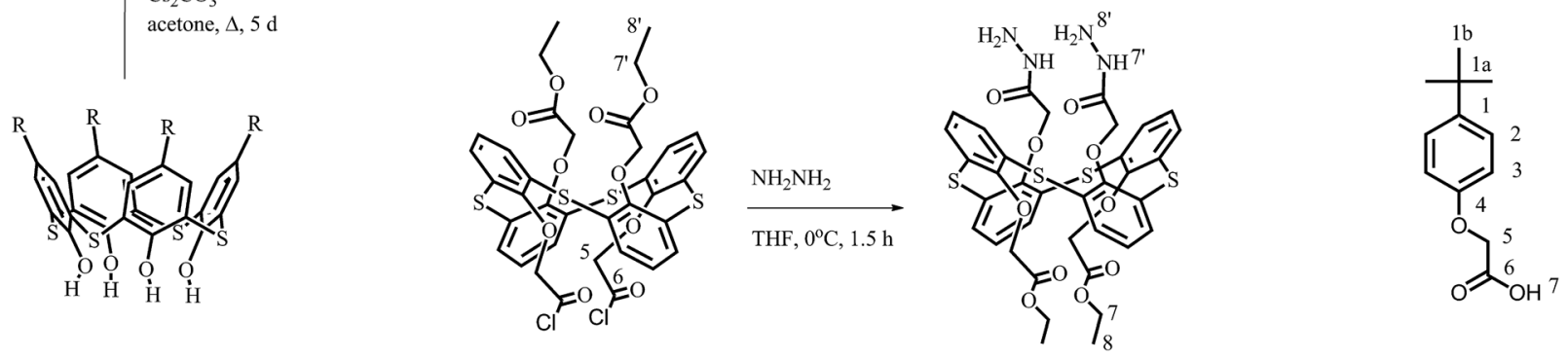

$1 \mathbf{a ~} \mathrm{R}=t-B u$

6

Fig. 1 Synthetic routes and structural formulae of the investigated compounds. Numbering system of atoms used in the experimental section. 
Table 1 The frequencies of characteristic vibrations $\left(\nu, \mathrm{cm}^{-1}\right)^{a}$ in the IR spectra of compounds

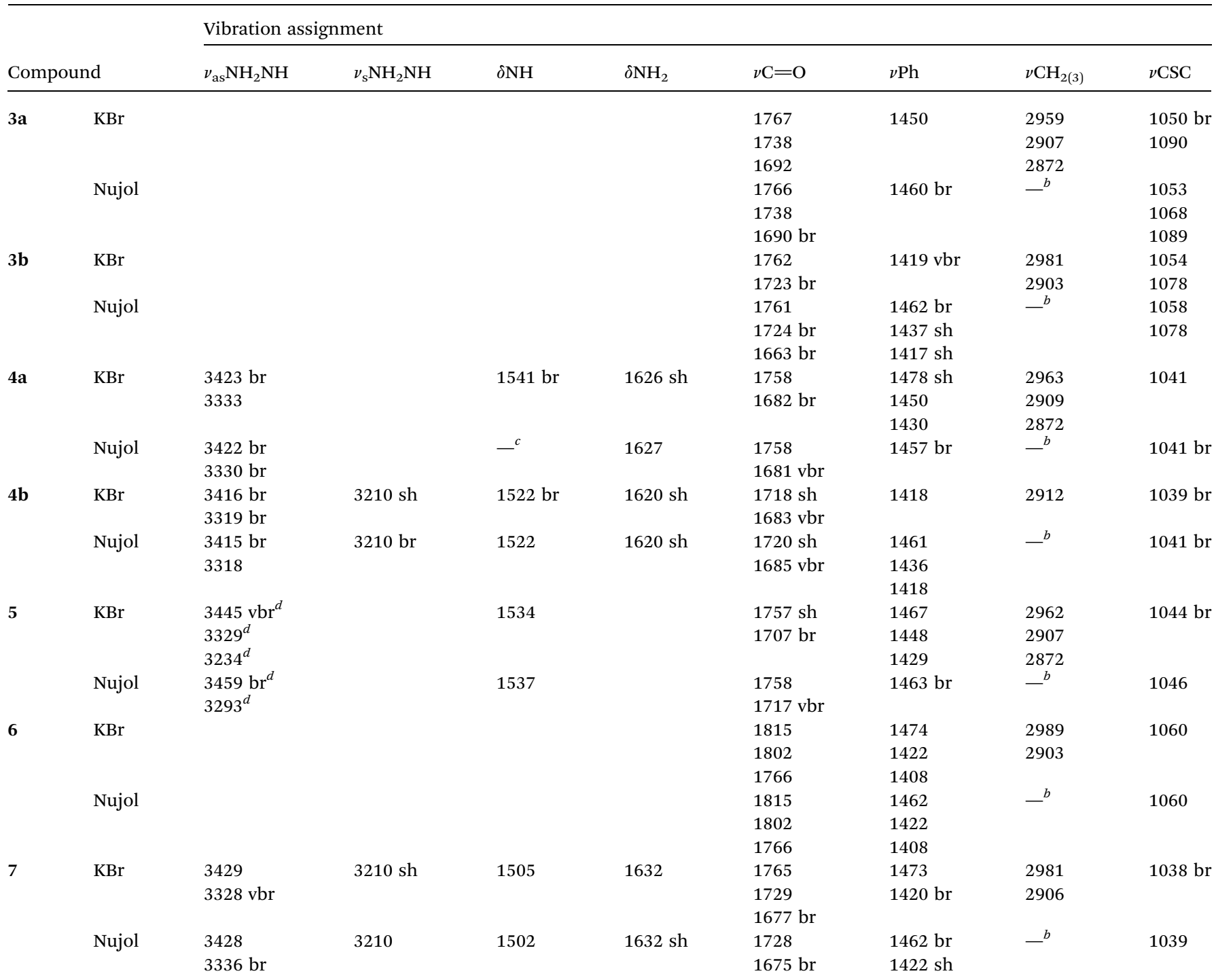

${ }^{a}$ Additional characteristics of absorption bands: sh - shoulder; br - broad; vbr - very broad. The maxima of rather intensive bands of signals are solid underlined. The maxima of weak intensive bands of signals are dashed underlined. ${ }^{b}$ Characteristic vibrations are not due to overlap with Nujol bands. ${ }^{c}$ Absorption band no detected. ${ }^{d}$ Characteritic vibrations of $\nu \mathrm{NH}$.

to the investigations accomplished in the last decade, the hydrazide derivatives of calix[4]arene can act as selective receptors for anions and cations. ${ }^{14,15,25-27}$ Furthermore, these compounds can be successfully applied as key reagents for the synthesis of various nitrogen containing derivatives, including acylhydrazones, acylsemicarbazones and heterocycles.

The tetrathiacalix[4]arenes $\mathbf{4 a}$ and $\mathbf{4 b}$ functionalized by acetylhydrazide groups have been prepared in $92 \%$ and $85 \%$ yields by the reflux of the corresponding tetrathiacalixarenyloxyacetic acid diesters $\mathbf{3 a}$ and $\mathbf{3} \mathbf{b}$ with an excess of $\mathrm{NH}_{2}-\mathrm{NH}_{2} \cdot \mathrm{H}_{2} \mathrm{O}$ in the THF-EtOH solution for 2 days (Fig. 1). The crude products isolated from the reaction mixture can include the hydrazine molecules captured due to the interactions with carboxylic groups of the tetrthiacalix[4]arene molecules. Therefore, for obtaining the hydrazine free products $\mathbf{4 a}$ and $\mathbf{4 b}$, the solid remainders were suspended in water and thereafter treated carefully with $\mathrm{HCl}$ to reach $\mathrm{pH} \sim 5$.

The condensation of dihydrazide 4 a with picolinaldehyde has been accomplished in DMF-EtOH solution by heating the mixture at $80{ }^{\circ} \mathrm{C}$ over $36 \mathrm{~h}$. After an appropriate treatment, the target dihydrazone 5 was obtained with the yield of $53 \%$.

The synthesis of diester-dihydrazide derivative 7 started from the diester-dicarbonic acid $\mathbf{3 b}$. At the first stage, $\mathbf{3 b}$ was converted into dichloroanhydride derivative $\mathbf{6}$ under treatment with thionyl chloride and reflux the mixture for $2 \mathrm{~h}$. A subsequent condensation of the crude product 6 with an anhydrous hydrazine dispersed in the absolute $\mathrm{THF}$ at $0{ }^{\circ} \mathrm{C}$ led to the formation of bifunctional derivative 7 with the yield $72 \%$. The synthesis should be carried out with a special accuracy, since a variety of by-products can be formed during the reaction. It 
should be also noted that we have attempted to obtain the compound $\mathbf{7}$ by the etherification of $\mathbf{4 b}$ in the presence of EtOH and $p$-toluenesulfonic acid, as a catalyst. However, the yield of a target product did not exceed $30 \%$.

In order to explore a complexation behavior of novel synthesized compounds, the monomeric carboxylic counterpart $\mathbf{8}$, as a structural block of tetrathiacalix[4]arenes $\mathbf{3 - 5}$, has been obtained from $p$-tert-butyl-phenoxyacetic acid ester. ${ }^{28}$

\subsection{IR characterization in solid}

IR spectra of $p$-tert-butyltetrathiacalix[4]arenes $\mathbf{3 a}, \mathbf{4 a}, \mathbf{5}$ differ from the spectra of tetrathiacalix[4]arenes $3 \mathbf{b}, \mathbf{4 b}, \mathbf{6}$ and $\mathbf{7}$ due to the presence in former of the intensive bands $\nu\left(\mathrm{CH}_{3}\right)$ at $\sim 2960$ $\mathrm{cm}^{-1}$ assigned to the tert-butyl groups enclosed in the structure of the compounds (see Table 1 and Fig. 1, 2, 5, 8, 11, 14 and 17 in ESI $\dagger$ ). In IR spectra of the compounds $\mathbf{3 a}$ and $\mathbf{3 b}$, the absorption bands $\nu \mathrm{C}=\mathrm{O}$ belonging to the ester groups have almost the same maxima $\left(1767 \mathrm{~cm}^{-1}\right.$ and $\left.1762 \mathrm{~cm}^{-1}\right)$. At the same time, the absorption bands $v \mathrm{C}=\mathrm{O}$ of carboxylic groups for 3a appear as two peaks at $1738 \mathrm{~cm}^{-1}$ and $1692 \mathrm{~cm}^{-1}$. In the case of $3 \mathbf{b}$, we observe a single but rather intensive peak at $1723 \mathrm{~cm}^{-1}$ in the spectrum obtained in $\mathrm{KBr}$ pellets. The second peak having a weak intensity and low-frequency was detected at 1663 $\mathrm{cm}^{-1}$ only in Nujol. The presence of both peaks in the spectra of $\mathbf{3 a}$ and $\mathbf{3 b}$ indicates obviously an occurrence as free carboxylic groups in the structure of the compounds and the groups participating in the hydrogen bonding as well.

The replacement of ester groups in the compounds on the hydrazide (for $\mathbf{4 a}$ and $\mathbf{4 b}$ ) or the hydrazone (for $\mathbf{5}$ ) ones leads to the appearance $\left(>3000 \mathrm{~cm}^{-1}\right)$ of complicated absorption bands in their spectra caused by $\nu \mathrm{NH}$ vibrations. The similar peaks are observed in the spectrum of dihydrazide derivative 7 as well. The presence of amide-II absorption band $(\delta \mathrm{NH} \sim 1520-1540$ $\mathrm{cm}^{-1}$ ) in the spectra of $\mathbf{4 a}, \mathbf{4 b}, \mathbf{5}$ and 7 indicates the transconformation of amide groups in the structure of these compounds. ${ }^{29-31}$ At the same time, an absorption band $\nu \mathrm{NH} \sim$ $3234 \mathrm{~cm}^{-1}$ which is also observed in the spectrum of the dihydrazone 5 proves a contribution of cis-form to the conformational composition of the compound.

The presence of low-frequency absorption bands $\nu_{\text {as }} \mathrm{NHNH}_{2}$ along side with high-frequency peaks $\left(3423 \mathrm{~cm}^{-1}\right.$ and 3333 $\mathrm{cm}^{-1}$ for $\mathbf{4 a}, 3416 \mathrm{~cm}^{-1}$ and $3318 \mathrm{~cm}^{-1}$ for $\mathbf{4 b}$ in $\mathrm{KBr}$ ) in the spectra of the compounds points to the fact that at least one of the hydrazide groups in these molecules participates in the hydrogen bonding. A similar picture is observed in the case of dihydrazone derivative $5\left(3445 \mathrm{~cm}^{-1}\right.$ and $\left.3329 \mathrm{~cm}^{-1}\right)$ as well.

An occurrence of hydrazide and carboxylic groups in the structure of the compounds $\mathbf{4 a}$ and $\mathbf{4 b}$ leads to the appearance in their spectra of a broad absorption peak (at $1680 \mathrm{~cm}^{-1}$ ) arising due to the overlap of $\nu \mathrm{C}=\mathrm{O}$ bands. In the case of $4 \mathrm{a}$, a low-intensity peak at $1758 \mathrm{~cm}^{-1}$ caused probably by the presence of free carboxylic groups is also detected. When going to the dihydrazone 5 , a broad absorption band $\nu \mathrm{C}=\mathrm{O}$ with a maximum at $1707 \mathrm{~cm}^{-1}$ was observed in the spectrum of this compound as well. The underfrequency for this vibration is obviously connected with the participation of carboxylic and hydrazone groups in the hydrogen bonding. However, the hydrogen bonds, in this case, are not so strong, as those formed in the compounds $4 \mathbf{a}$ and $\mathbf{4 b}$. In the case of spectra $\mathbf{6}$, the doublet $\nu(\mathrm{C}=\mathrm{O})$ at $1815 \mathrm{~cm}^{-1}$ and $1802 \mathrm{~cm}^{-1}$ for chloroanhydride groups and a sharp single peak for ester groups at 1766 $\mathrm{cm}^{-1}$ are observed in $\mathrm{KBr}$. An absorbance $\nu(\mathrm{C}=\mathrm{O})$ of ester groups for the compound 7 is detected exactly at the same frequency $\left(1765 \mathrm{~cm}^{-1}\right)$ but appears as a quiet low intensive peak. At the same time, an absorbance of $\nu \mathrm{C}=\mathrm{O}$ of hydrazide groups is revealed as two peaks having an equal intensity at $1729 \mathrm{~cm}^{-1}$ and $1677 \mathrm{~cm}^{-1}$, indicating the involving only one of the carbonyl oxygen atoms of these groups in the hydrogen bonding.

The hydroxyl groups appear as a broad dome-shaped $\nu(\mathrm{OH})$ band in IR spectra of the compounds $\mathbf{3 a}, \mathbf{3} \mathbf{b}, \mathbf{4} \mathbf{a}$ and $\mathbf{4 b}$. This band is underneath the $\nu(=\mathrm{CH}), \nu(-\mathrm{CH})$ and $\nu(\mathrm{NH})$ absorptions in the region $\sim 3500-3100 \mathrm{~cm}^{-1}$ with a center being around $\sim 3400 \mathrm{~cm}^{-1}$ for $\mathbf{3 a}, \mathbf{3 b}$ and $\sim 3250 \mathrm{~cm}^{-1}$ for $\mathbf{4 a}$ and $\mathbf{4 b}$. These values of frequency are lower than ones observed for the stretching vibrations of free hydroxyl groups $\left(\sim 3500 \mathrm{~cm}^{-1}\right)$, that proves their participation in the formation of H-bonds. In the case of dihydrazone derivative $\mathbf{5}$, the absorbance $\nu(\mathrm{OH})$ has more broadened shape with an uncertain maximum.

\subsection{X-ray analysis}

Suitable for X-ray analysis the colorless crystals of dihydrazides $\mathbf{4 a}$ and $\mathbf{4 b}$ were obtained by the recrystallization of their crude products from $\mathrm{MeOH}-\mathrm{CH}_{2} \mathrm{Cl}_{2}$. We have also succeeded in the preparing the crystals of $\mathbf{4 a}$ in DMSO when treated a crude product with $\mathrm{HCl}$ (see Experimental part). In former case, 4a and $\mathbf{4 b}$ calix[4]arenes were crystallized with the capturing two

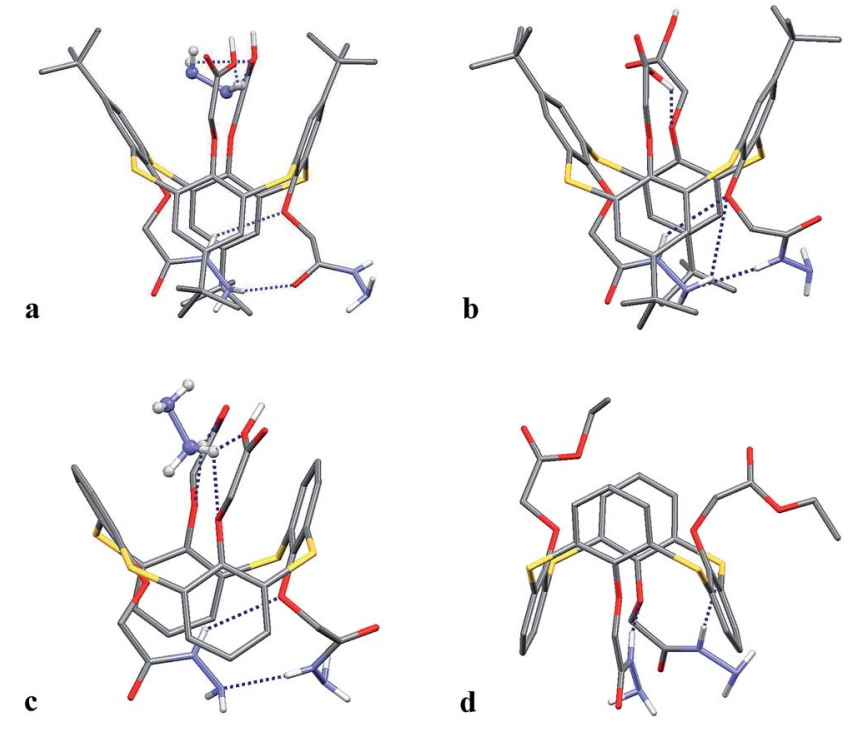

Fig. 2 The structures of compounds (a) $4 \mathrm{a} \cdot 2 \mathrm{NH}_{2} \mathrm{NH}_{2}$; (b) $4 \mathrm{a}$; (c) $4 \mathrm{~b} \cdot \mathrm{NH}_{2} \mathrm{NH}_{2}$ and (d) 7 in the crystals. Only hydrogen atoms of $\mathrm{OH}$ and $\mathrm{NH}$ groups are shown. The disordered fragments are shown in positions with the highest occupancy. In the cases of (a) - the hydrazine molecule, (b) - the DMSO molecule and (c) - the water molecules outside of the thiacalix[4]arene cavity are not shown. 
and one hydrazine molecules, affording consequently the structures $4 \mathbf{a} \cdot \mathbf{2} \mathbf{N H}_{2} \mathbf{N H}_{2}$ (Fig. 2a) and $\mathbf{4 b} \cdot \mathbf{N H}_{2} \mathbf{N H}_{\mathbf{2}}$ (Fig. 2c). In the second case, the crystals of $\mathbf{4 a}$ were obtained without inclusion the hydrazine in their structure (Fig. 2b). The recrystallization of dihydrazide 7 from $\mathrm{MeOH}-\mathrm{CH}_{2} \mathrm{Cl}_{2}$ has also brought the crystals do not containing hydrazine molecules (Fig. 2d). In the last case, the product was treated by water without adding $\mathrm{HCl}$. The presence of carboxylic groups in $\mathbf{4 a}$ and $\mathbf{4 b}$ in contrast to 7 is obviously a main reason for the hydrazine binding by these compounds. The acidification of $\mathbf{4 a}$ and $\mathbf{4 b}$ solutions prevents the amine coordination. The crystals of dihydrazone 5 were obtained from $\mathrm{MeOH}-\mathrm{CH}_{2} \mathrm{Cl}_{2}$ as well. All considered bifunctional derivatives $\mathbf{4 a}, \mathbf{4 b}, \mathbf{5}$ and 7 possess the 1,3-alternate isomer form established for their parent $\mathbf{3 a}$ and $\mathbf{3 b}$ tetrathiacalix[4]arenes previously.

The compound $\mathbf{4 a} \cdot \mathbf{2} \mathbf{N H}_{2} \mathbf{N H}_{2}$ crystallizes in $C 2 / c$ space group with one hydrazine molecule being in thiacalix[4]arine's cavity and the another one being outside (Fig. 2a). The highly disordered solvent molecules can be localized between thiacalix[4] arene molecules in the crystal and occupy up to $1307 \AA^{3}$ per unit cell. However, it should be noticed that these solvate molecules could not be detected properly using Fourier electron density synthesis under normal X-ray experiment conditions. A coordination of hydrazine molecules by the thiacalix[4]arene $4 \mathbf{a}$ leads to an increase only one from four of dihedral angles formed by the aromatic moieties and a reference plane passing through sulfur atoms (for compare in 4a: 119.1(2) ${ }^{\circ}, 113.1(2)^{\circ}$, $116.0(2)^{\circ}$ and $116.0(2)^{\circ}$; in $\mathbf{4 a} \cdot 2 \mathbf{N H}_{2} \mathbf{N H}_{2}: 127.4(2)^{\circ}, 109.1(2)^{\circ}$, $105.7(2)^{\circ}$ and $\left.108.3(2)^{\circ}\right)$.

The hydrazine free thiacalix[4] arene 4 a crystallizes in $P 2_{1} / n$ space group with one DMSO molecule per macrocycle directed outside of the cavity (Fig. 2b). All tert-butyl groups are disordered over two positions with relative occupancies: $0.77: 0.23$, $0.60: 0.40,0.65: 0.35$ and $0.65: 0.35$. The carboxylic group is also disordered over two positions with a relative occupancy being $0.57: 0.43$. Inequality of bond lengths in carboxylic groups indicate that both $-\mathrm{COOH}$ substituents in the molecule are not deprotonated.

The realization of classical hydrogen bonds in the molecules of thiacalix[4]arene $\mathbf{4 a}$ results in the formation of H-dimers in the crystals due to the interaction between hydrazide groups of the centro-symmetrical pairs of molecules, whereas the carboxylic groups do not form intra- and intermolecular hydrogen bonds between each other. It is obviously caused by the fact that one of the carboxylic groups is involved in the hydrogen bonding with DMSO molecule located in the macrocycle cavity, and the another one participates in the intramolecular hydrogen bonding with ester oxygen of an opposite phenoxylic fragment of the thiacalix[4]arene framework.

The compound $\mathbf{4 b} \cdot \mathbf{N H}_{\mathbf{2}} \mathbf{N H}_{2}$ crystallizes in $P 2_{1} / c$ space group. The asymmetric part of the unit cell contains one thiacalix[4] arene molecule together with one hydrazine molecule being inside (Fig. 2c), as in the case of $\mathbf{4 a} \cdot \mathbf{2} \mathbf{N H}_{2} \mathbf{N H}_{2}$, and four cocrystallized water molecules located outside the cavity. Dihedral angles between aromatic moieties and a reference plane passing through sulfur atoms $\left(109.3(1)^{\circ}, 104.1(1)^{\circ}, 100.7(1)^{\circ}\right.$ and $\left.123.6(1)^{\circ}\right)$ are slightly less than the corresponding values for 4a. An absence of bulky tert-butyl groups at the upper rim of thiacalix[4]arene favours the tube-shaped structure of $\mathbf{4 b}$ which is clear observed for this compound even under encapsulation.

Insufficiently high quality of $\mathbf{4 a} \cdot \mathbf{2} \mathbf{N H}_{2} \mathbf{N H}_{\mathbf{2}}$ and $\mathbf{4 b} \cdot \mathbf{N H}_{\mathbf{2}} \mathbf{N H}_{\mathbf{2}}$ crystals prevents a deep analysis of the bond distances and angles in these molecules as well as makes difficult a precise determination of the hydrogen atoms in $\mathrm{OH}$ and $\mathrm{NH}_{2}$ groups. Nevertheless, it is clearly seen that the hydrazine molecule is coordinated due to the participation of both carboxylic groups. It should be also noticed that dicarboxylic tetrathiacalix[4]arene derivatives can generate a formation of salt structures with an involvement of deprotonated carboxylic group of macrocycle and the hydrazinium ion.

The dihydrazide 7 crystallizes in $P 2_{1} / c$ space group. The asymmetric part of the unit cell comprises just one thiacalix[4] arene molecule and does not enclose solvate molecules (Fig. 2d). The dihedral angles between the aromatic moieties and the plane defined by four sulfur atoms were determined as $111.5(1)^{\circ}, 99.1(1)^{\circ}, 105.2(1)^{\circ}$ and $115.8(1)^{\circ}$. One of the hydrazide and one of the ester groups are disordered over two positions with relative occupancy ratios of $0.45: 0.55$ and $0.42: 0.58$, respectively. The hydrazide substitutes are involved in intramolecular as well as the intermolecular hydrogen bonds simultaneously, which results in 3D supramolecular structure formed by 7 in the crystal.

The dihydrazide derivatives $\mathbf{4 a}, \mathbf{4 b}$ and 7 have trans-amide conformation of the acetylhydrazide fragments and the nonhydrogen atoms of these groups are located practically at the same plain. One of the hydrazide substituents closes a pseudocavity of the thiacalix[4]arene and prevents a penetration of solvent molecules (Fig. 2a-d). Moreover, this spatial structure of the molecules is additionally stabilized by a system of intramolecular and intermolecular hydrogen bonds.

Dihydrazone derivative 5 crystallizes in $P \overline{1}$ space group. The asymmetric part of the unit cell contains one thiacalix[4]arene molecule and one methanol molecule which acts as a bridge between two hydrazone fragments (Fig. 3). Dihedral angles between aromatic moieties and a reference plane passing through sulfur atoms are $116.9(5)^{\circ}, 103.7(5)^{\circ}, 105.3(5)^{\circ}$ and $110.3(4)^{\circ}$. One of the tert-butyl groups is disordered over two positions with a relative occupancy ratio of $0.54: 0.46$.
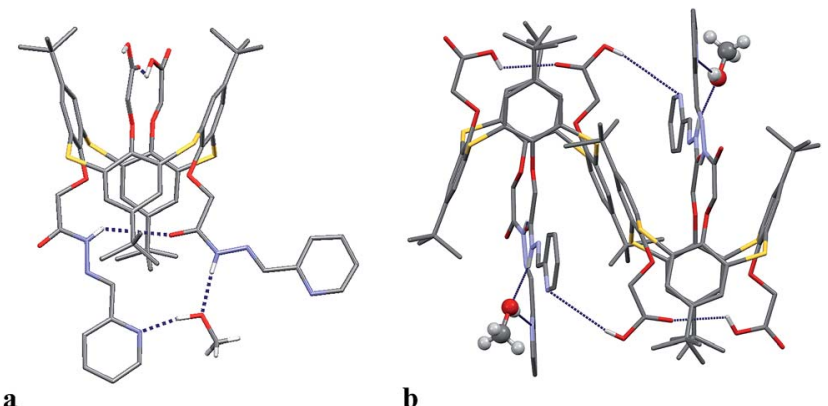

b

Fig. 3 The geometry of the molecule (a) and $\mathrm{H}$-dimer (b) in the crystal of 5 in the crystal. Hydrogen atoms are not shown, except for the hydrazone and carboxyl groups of 5 and $\mathrm{MeOH}$. 


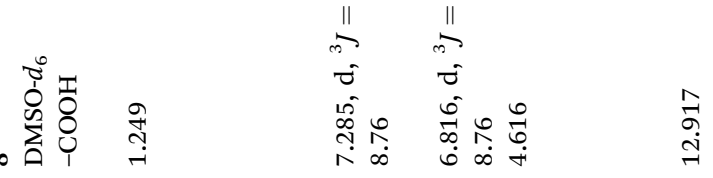

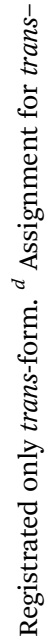

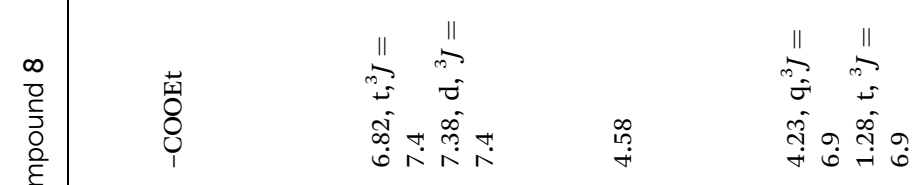

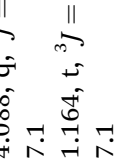

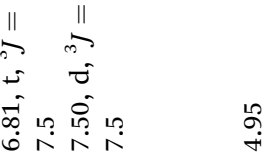

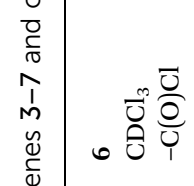

$\stackrel{11}{\Rightarrow}=$

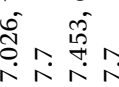

$\underset{\substack{\infty \\+}}{+\infty}$

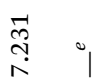

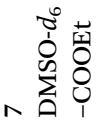

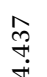

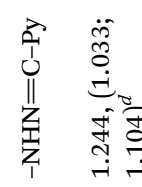

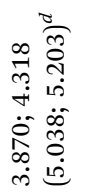

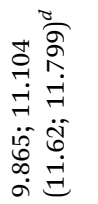

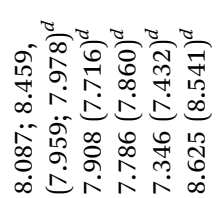

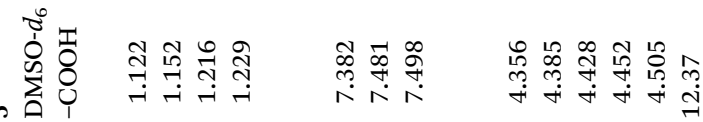

in

仓产茕

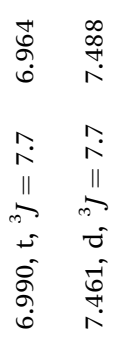

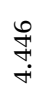

oุ

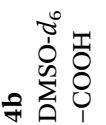

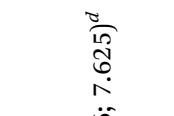

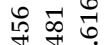

๙ุ

(n)

亏े

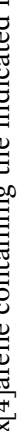

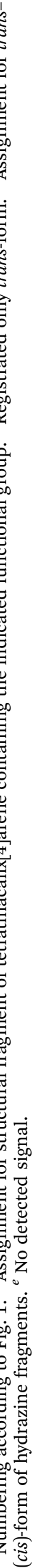


In the case of tetrathiacalix[4]arene 5, both acetylhydrazone substitutes are characterized by the flattened structure and are described by $E_{\mathrm{N}-\mathrm{N}} E_{\mathrm{C}=\mathrm{N}}$ configuration which is typical for acetylhydrazones in crystal. ${ }^{32}$ At the same time, one of the acetylhydrazone fragments has cis-conformation and the another one is in the trans-amide form. The previously investigated tetra-acetylhydrazone derivatives of thiacalix[4]arene were also characterized by an equal ratio of cis/trans-amide conformers. However, the acetylhydrazones, according to CSD data, prefer the trans-amide conformation ( $94 \%$ of all structures). ${ }^{32} \mathrm{~A}$ mutual influence of the hydrazone fragments immobilized on the macrocyclic platform leads obviously to an equalization of the conformational content. The acetylhydrazone fragments are interconnected directly via the intramolecular hydrogen bonds and by means of the bridge interaction with participation of the hydroxyl groups of $\mathrm{MeOH}$ as well.

In spite of the fact that strong donor and acceptor groups are present in the molecule 5, only pair interactions between the hydroxyl groups of carboxylic substitutes of one molecule and the pyridine nitrogen atoms of a neighboring molecule are realized in the crystal. These interactions result in the formation of centrosymmetric $\mathrm{H}$-dimers (or pseudo-tetramers, if two solvate $\mathrm{MeOH}$ molecules are taking into account). Such type of the molecules' arrangement, however, does not lead to the closest packing. Indeed, the voids revealed in the crystals occupy up to $246 \AA^{3}$ per unit cell and can be filled up by the highly disordered solvent molecules.

\subsection{NMR characterization in solution}

The ${ }^{1} \mathrm{H}$ and ${ }^{13} \mathrm{C}$ spectra of bifunctional derivatives $4 \mathbf{a}, \mathbf{4 b}, \mathbf{6}$ and 7 as well as the spectra of starting compounds $\mathbf{3 a}$ and $\mathbf{3 b}$ described by us earlier ${ }^{24}$ show two sets of signals assigned to tetrathiacalix[4]arene scaffold (Table 2 and 3), although each of $-\mathrm{OCH}_{2} \mathrm{R}$ pairs of functional groups produces only one combination of signals. Such spectral picture for the synthesized compounds is in a full agreement with their expected structure and is typical for the distal location of the identical substitutes in molecule.

The determination of the isomer form for the "classical" calix[4]arenes containing methylene bridges in their structure can be easily performed by using a simple "de Mendoza rule".,33 In the case of tetrathiacalix[4]arenes, a more sophisticated analysis of the chemical shifts for other groups of atoms in comparison with the model compounds as well as 2D NMR experiments are usually required. However, in our case, the situation is simplified due to the fact that $n$-butyl groups are just bulky enough to prevent rotation of the alkylated phenolic rings through the main annulus of thiacalix[4]arene, at least at temperatures up to $413 \mathrm{~K}^{34}$ Since the synthetic pathway to the desired compounds started from the conformationally immobilized 1,3-alternate precursors $\mathbf{3 a}$ and $\mathbf{3 b}$ with well documented structures, ${ }^{24}$ we have assumed that their derivatives $4 \mathbf{a}, 4 \mathbf{b}, 6$ and 7 would also adopt the 1,3-alternate isomer form. The $2 \mathrm{D}$ NOESY experiments for the compounds 4-7 have been nevertheless accomplished to confirm this fact. Really, the crosspeaks between aromatic and tert-butyl protons and the protons

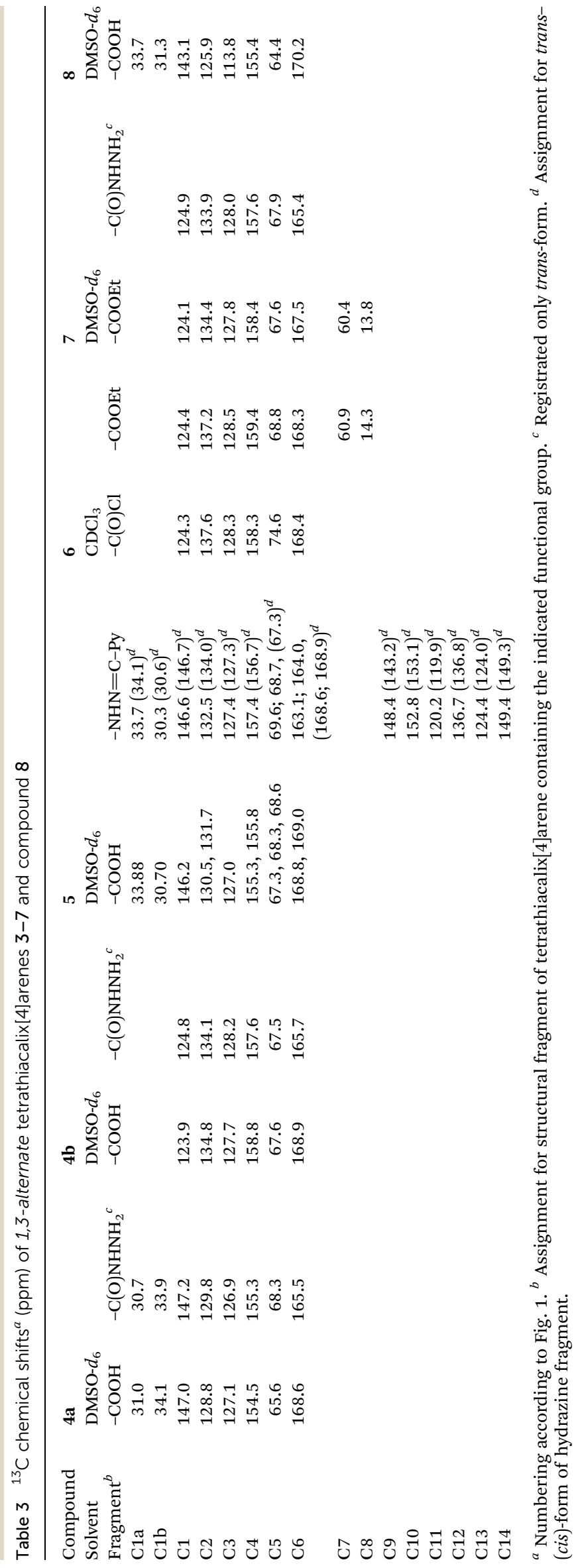




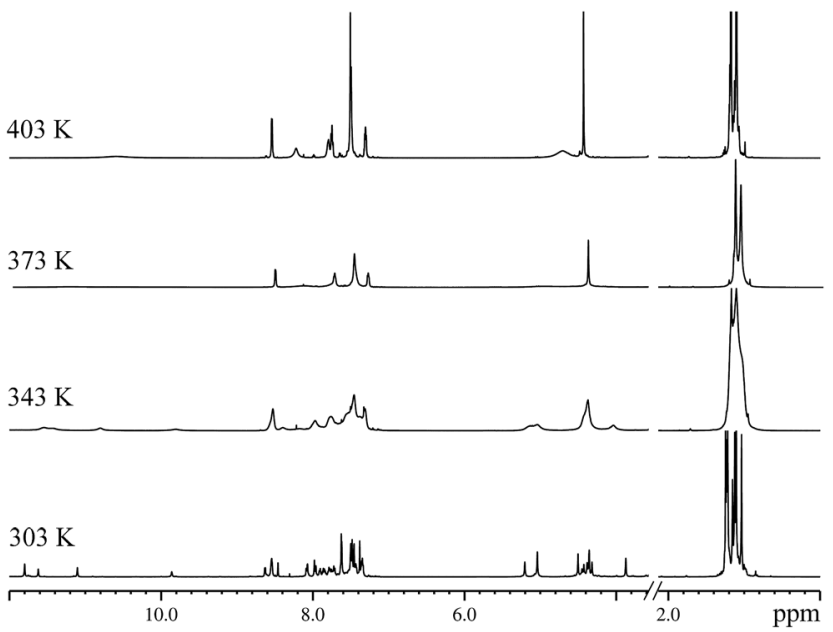

Fig. 4 The influence of the temperature change $303 \mathrm{~K} \rightarrow 403 \mathrm{~K}$ on ${ }^{1} \mathrm{H}$ NMR spectra of the dihydrazone tert-butyltetrathiacalix[4]arene 5 .

of $\mathrm{OCH}_{2}-$ groups belonging to the acid or hydrazide fragments of the adjacent structural blocks of tetrathiacalix[4]arene were detected in the spectrum of $\mathbf{4 a}$. It is quite clear that only in the case of the 1,3-alternate isomer, these cross-peaks could be observed. The similar picture was characteristic for all synthesized compounds 4-7.

It could be expected that an occurrence of amide fragments in the structures of $\mathbf{4 a}, \mathbf{4 b}, \mathbf{5}$ and 7 should result in the complication of their spectra due to the realization of cis- and trans-amide conformers for these compounds. In the case of compound 5, a formation of additional spatial forms is also possible due to $E / Z$ isomerization relative to the $\mathrm{C}=\mathrm{N}$ double bond. Indeed, a great number of peaks as well as the broadening and overlapping signals are observed in ${ }^{1} \mathrm{H}$ NMR spectrum of dihydrazone 5 at $303 \mathrm{~K}$ (Fig. 4). The various spatial forms for hydrazones have been analyzed carefully and discussed in detail in our previous publications. ${ }^{35,36}$ In accordance with the spectral criteria suggested in these articles, we have performed a conformational assignment for the investigated compounds and represented the results in the Tables 2 and 3

It was established that only trans-amide conformer is realized for dihydrazides $\mathbf{4 a}, \mathbf{4 b}$ and 7 . The hydrazone fragments in 5 were found to exist in $E_{\mathrm{C}=\mathrm{N}}$ isomer form. It is worth noting that the trans-form content for the compound 5 equals $42 \%$ and is practically similar to the conformational composition determined for the corresponding 4-tert-butylphenoxyacetylhydrazone $(40 \%)^{35}$ as well as for 1,3-alternate tetrahydrazone $p$-tertbutyltetrathiacalix[4]arene $(44 \%) .^{32}$

It was shown in our previous investigations that UV irradiation of 4-tert-butylphenol and resorcinol acetylhydrazone derivatives resulted in a partly conversion of the $E_{\mathrm{C}=\mathrm{N}}$ into the $Z_{\mathrm{C}=\mathrm{N}}$ isomer. ${ }^{31,35}$ According to NMR data, the stabilization of $Z_{\mathrm{C}=\mathrm{N}}$ isomer in these compounds was provided due to the occurrence of intramolecular hydrogen bonds between $\mathrm{NH}$ protons and the nitrogen atoms of 2-pyridinyl substitutes in the hydrazone fragments. However, the irradiation of $\mathrm{CDCl}_{3}$ solution of the compound 5 by UV light for $2 \mathrm{~h}$ did not lead to the
$E_{\mathrm{C}=\mathrm{N}} / Z_{\mathrm{C}=\mathrm{N}}$ isomerization. Such situation was observed by us earlier for the calix[4]resorcinol and tetrathiacalix[4] arene (cone and 1,3-alternate) acetylhydrazone derivatives also. ${ }^{31,36}$ The presence of neighboring acetylhydrazone groups capable of participating in intramolecular interactions as well as the sterical hindrances realized in tetrathiacalix[4]arene and calix[4] resorcine macrocycles prevent evidently the UV-induced $E_{\mathrm{C}=\mathrm{N}} /$ $Z_{\mathrm{C}=\mathrm{N}}$ isomerization.

An occurrence of a large number of polar groups possessing acceptor and donor properties makes possible for the investigated compounds a formation of dimer and even substantially greater molecular aggregates in low-polarity solvents. It could be expected that the compounds $\mathbf{4 a}$ and $\mathbf{4 b}$ bearing the carboxylic and hydrazide groups capable of formation of a various type of intermolecular hydrogen bonds are greatly predisposed to the generation of such aggregates. To check this assumption, we have applied a diffusion NMR method which is commonly used for studying an aggregation in host-guest systems ${ }^{37}$ and investigating of the hydrogen-bonded assemblies in the solution-phase. ${ }^{38,39}$

NMR DOESY experiments performed for the compounds $4 a$ and $\mathbf{4 b}$ in the mixture of $\mathrm{CDCl}_{3}-\mathrm{CD}_{3} \mathrm{OD}(1: 1)$ have demonstrated that the investigated bifunctional derivatives does not form even dimers at the concentrations up to $30 \mathrm{mM}$. The analysis of a change of self-diffusion coefficients under increase of the ligand's concentration showed that the amount of the dimeric molecules for these compounds does not exceed $5 \%$. It should be noticed that we have previously investigated the aggregation properties of dicarbonic acid $\mathbf{3 b}$ possessing a dimeric structure in the crystal. ${ }^{24}$ It appeared to our surprise that in $\mathrm{CDCl}_{3}$ solution the percentage of $\mathbf{3 b}$ molecules adopting the dimer form was not above $25 \%$.

To summarize NMR experiments, we can conclude that the complication of NMR spectra for the compounds 4-7 may be caused, first of all, by the intramolecular interactions of functional groups and, in the case of the compound $\mathbf{5}$, by cis/trans amide conformational isomerism. The magnetic anisotropy of aromatic rings in 1,3-alternate isomer may additionally complicate the spectra of these compounds. This influence is especially noticeable for the compound $\mathbf{5}$. Thus, the signals of methylene groups (H5) of acetylhydrazone fragments having trans-conformation differ on $0.45 \mathrm{ppm}$ (Table 2 and Fig. 4). Under heating the samples up to $373 \mathrm{~K}$, the proton peaks of carboxylic groups as well as the peaks of hydrazone group protons for different conformers coalesce and converge into sharp lines at $403 \mathrm{~K}$. Under cyclic temperature changes $303 \mathrm{~K} \rightarrow$ $403 \mathrm{~K} \rightarrow 303 \mathrm{~K}$, the spectral picture does not change, which testifies to the maintenance of the structural content for the compound 5.

\subsection{Extraction studies}

The liquid-liquid extraction experiments were performed to examine the efficiency and selectivity of tetrathiacalix[4]arene derivatives $\mathbf{3 a}, \mathbf{3 b}, \mathbf{4 a}, \mathbf{4 b}, \mathbf{5}, \mathbf{7}$ and their monomeric counterpart 8 in transferring of s- $\left(\mathrm{Na}^{+}, \mathrm{Ca}^{2+}\right), \mathrm{p}-\left(\mathrm{Pb}^{2+}\right)$ and d- $\left(\mathrm{Co}^{2+}, \mathrm{Ni}^{2+}\right.$, $\mathrm{Cu}^{2+}, \mathrm{Zn}^{2+}, \mathrm{Ag}^{+}$and $\left.\mathrm{Cd}^{2+}\right)$ metal ions from aqueous phase into 

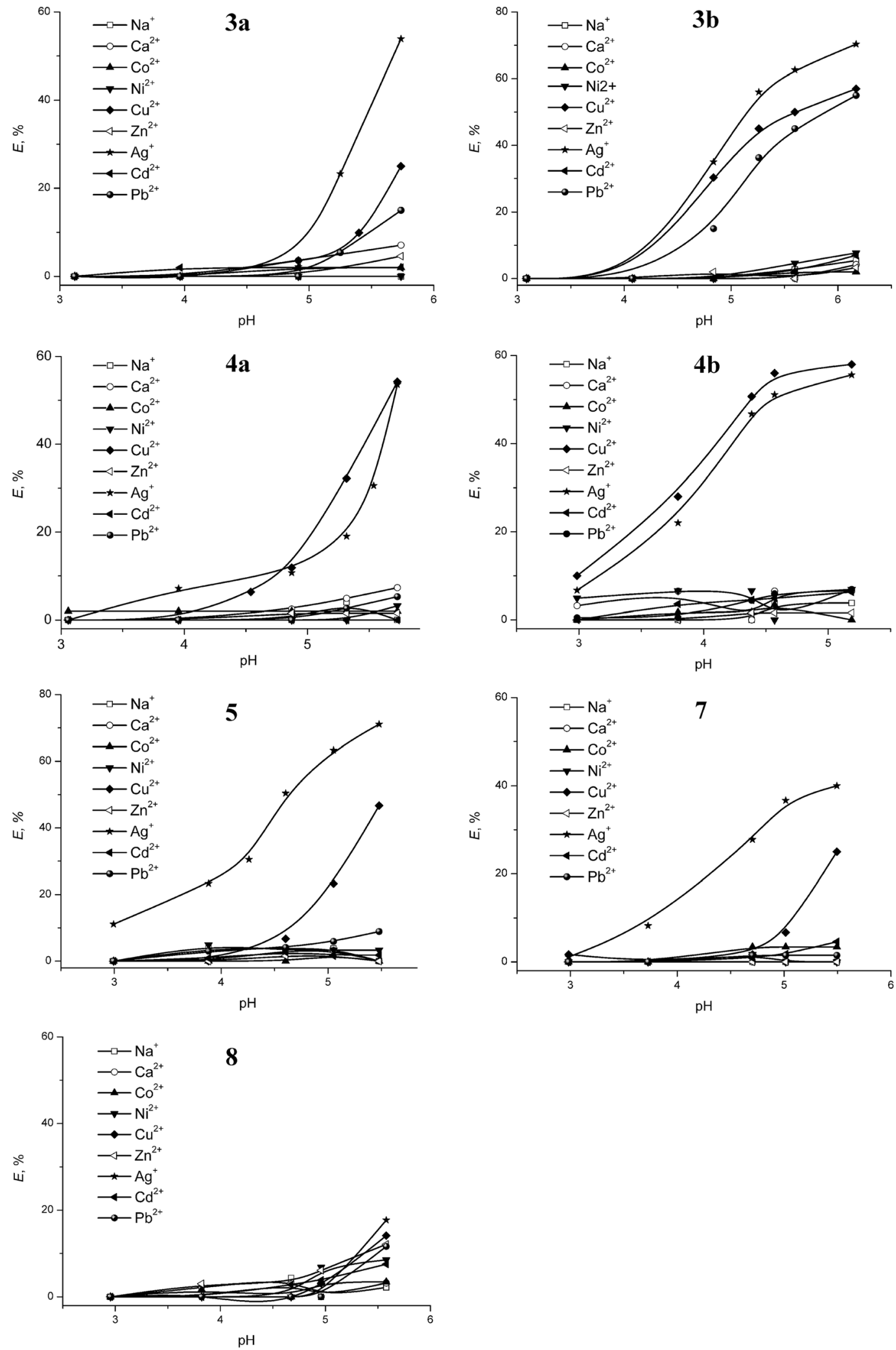

Fig. 5 Effect of $\mathrm{pH}$ on the extraction percentage (E\%) for different metal ions recovered by the ligands 3-7. [L] $=0.2 \mathrm{mM}$, [metal ion] $=0.1 \mathrm{mM}$, shaking time $=2 \mathrm{~h}$ at $298 \mathrm{~K}$, phase ratio $1: 1(\mathrm{v} / \mathrm{v}), \mathrm{pH}$ was adjusted with $\mathrm{HNO}_{3}$ and Tris buffer. 
chloroform at various $\mathrm{pH}$ (Fig. 5). The concentrations of ligands in chloroform and metal cations in aqueous phase were identical in all experiments.

It was established that an increase of $\mathrm{pH}$ of the aqueous phase up to $\mathrm{pH} \sim 5-6$ leads to the enhancement of extraction ability of the investigated compounds towards metal ions. This phenomenon obviously may be explained by the ionization of carboxylic groups of the compounds at high $\mathrm{pH}$, except the compound 7. From the other hand, a presence of lone electron pairs at the nitrogen atoms in dihydrazides $4 \mathbf{a}, \mathbf{4 b}, 7$ and dihydrazone $\mathbf{5}$ provides their basic properties. The protonation of hydrazide and hydrazone groups in these compounds, proceeding at the interface in acid conditions, prevents their complex formation with metal cations. This fact seems to be a main reason of the $\mathrm{pH}$ depending extraction revealed by the compound 7 having an incapable of deprotonation ester groups instead of the carboxylic ones.

All tetrathiacalix[4]arene derivatives 3-7 and the compound 8 have demonstrated a poor extraction towards s-elements $(E<$ $5 \%$ for $\mathrm{Na}^{+}$and $E<5 \%$ for $\mathrm{Ca}^{2+}$ ). At the same time, the tetrathiacalix[4]arene derivatives recovered selectively certain d- and $\mathrm{p}$ - ions at $\mathrm{pH} \sim 5-6$. The selectivity of the ligands $\mathbf{3 a}$ and $\mathbf{3 b}$ towards the metal ions is reduced in the row $\mathrm{Ag}^{+}>\mathrm{Cu}^{2+}>\mathrm{Pb}^{2+}$.

The extraction efficiency goes up after removing tert-butyl groups from the upper rim of 1,3-alternate tetrathiacalix[4]arene on going from $3 \mathbf{a}$ to $3 \mathbf{b}$ : $54 \%$ and $70 \%$ for $\mathrm{Ag}^{+}, 25 \%$ and $57 \%$ for $\mathrm{Cu}^{2+}, 15 \%$ and $45 \%$ for $\mathrm{Pb}^{2+}$. In spite of decreasing the lipophilicity of the molecules, the weakening of steric difficulties obviously facilitates a process of metals recovery by the compound $\mathbf{3 b}$. It should be noted that the monomeric carboxylic acid 8 can also recover the $\mathrm{Ag}^{+}(18 \%), \mathrm{Cu}^{2+}(14 \%)$ and $\mathrm{Pb}^{2+}$ (11\%) metal ions from aqua solutions, but the efficiency and selectivity are substantially lower than for tetrathiacalix[4]arene derivatives. It is worth noting that in the case of carboxylic derivatives of calix[4]-, [5]- and [6]arenes, a more effective binding of $\mathrm{Pb}^{2+}$ relatively $\mathrm{Cu}^{2+}$ has been established earlier. ${ }^{40-44}$

A replacement of ester groups by the hydrazide ones for $\mathbf{4 a}$ and $\mathbf{4 b}$ leads to the dramatic decrease of the extraction efficiency towards $\mathrm{Pb}^{2+}$ ion (up to 5-7\%). At the same time, the efficiency of the $\mathrm{Ag}^{+}$and $\mathrm{Cu}^{2+}$ ions recovery by these compounds remains the same. It is known that calix[n]arenes may exhibit an allosteric effect,,$^{22,23,45}$ which was previously detected for the binding of $\mathrm{Pb}^{2+}$ ions by the calix $[5,6]$ arene carboxylic derivatives. ${ }^{43,46}$ In the case of tetrathiacalix[4]arenes $\mathbf{4 a}$ and $\mathbf{4 b}$, the replacement of ester groups on the hydrazide ones can influence on the preorganization of carboxylic binding center similar to the allosteric effect. The hydrazide groups in the calix[4]arenes $\mathbf{4 a}, \mathbf{4 b}$ and 7 , in contrast to the ester ones in the compounds $\mathbf{3} \mathbf{a}$ and $\mathbf{3} \mathbf{b}$, are connected by the intramolecular hydrogen bonds (Fig. 2). Such circumstance obviously influences not only on the geometrical parameters, but on the rigidity of the molecules as well. For the dihydrazide derivatives $\mathbf{4} \mathbf{a}$ and $\mathbf{4 b}$, these factors lead to a negative effect in the binding of $\mathrm{Pb}^{2+}$ ion which has greater ionic radius $(1.19 \AA)$ than $\mathrm{Ag}^{+}(0.67 \AA)$ and $\mathrm{Cu}^{2+}(0.73 \AA)$ ions. ${ }^{47}$

An enhanced efficiency of $\mathrm{Ag}^{+}(71 \%)$ and $\mathrm{Cu}^{2+}(47 \%)$ ions recovery is observed for the hydrazone $\mathbf{5}$ in comparison with $\mathbf{3 a}$ and $4 \mathrm{a}$. This fact is apparently caused by the simultaneous

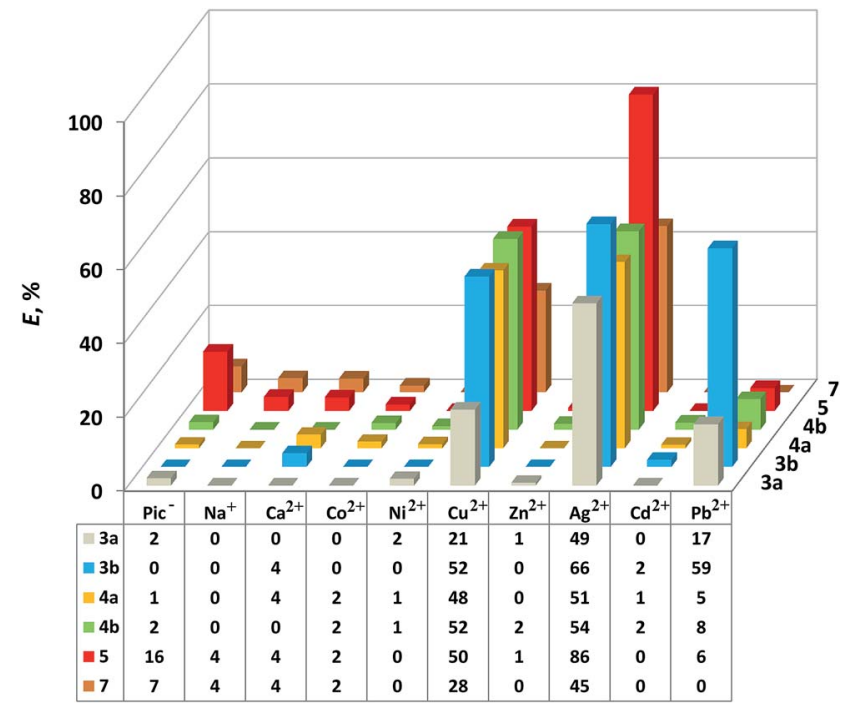

Fig. 6 Extraction percentage (E\%) for cations and $\mathrm{Pic}^{-}$as a function of the nature of ligands 3-7. [L] $=0.2 \mathrm{mM}$, [Metal ion] $=0.1 \mathrm{mM}$, [HPic] $=$ $0.4 \mathrm{mM}$, shaking time $=2 \mathrm{~h}$ at $298 \mathrm{~K}$, phase ratio $=1: 1(\mathrm{v} / \mathrm{v}), \mathrm{pH}=6 \pm$ 0.1 was adjusted with $\mathrm{HNO}_{3}$ and Tris buffer.

cooperative participation of the carboxylic and hydrazone binding centers in the coordination of these cations.

In the case of dihydrazide 7 which does not have the carboxylic groups in its structure, a noticeable extraction of $\mathrm{Ag}^{+}$ $(40 \%)$ and $\mathrm{Cu}^{2+}(25 \%)$ cations is also observed. It was previously shown by the picrate liquid extraction method that 1,3-alternate tetrahydrazide of $p$-tert-buthyl-tetrathiacalix[4]arene has revealed a high extraction efficiency exactly for these metal ions, whereas its de-tert-butyl analogue extracted more effectively in the row $\mathrm{Ag}^{+}>\mathrm{Ni}^{2+}>\mathrm{Cu}^{2+}>\mathrm{Cd}^{2+} \cdot{ }^{15}$ Generally, the data obtained for the selectivity of dihydrazide 7 are in accordance with the previously obtained results.

It should be noticed that the recovery of metal cations by the compound 7 can proceed only with participation of a counterion, but in the case of the compounds $3 \mathbf{a}, 3 \mathbf{b}, \mathbf{4 a}, \mathbf{4 b}, \mathbf{5}$ and $\mathbf{8}$, the extraction is probably realized via the ion-exchange process. To support this assumption we have performed an extraction experiment in the presence of $\mathrm{Pic}^{-}$anion in aqua phase at $\mathrm{pH}=$ $6 \pm 0.1$ (Fig. 6).

Picrate is known to form preferentially second sphere complexes and can easier than "hard anions" be transferred from aqua to organic phase due to its enhanced lipophilic properties. ${ }^{48} \mathrm{~A}$ transfer of this anion can be readily detected by UV-Vis spectrophotometric method. The analysis of the obtained UV data testified that the extraction of metal cations by the dihydrazide 7 proceeds with the participation of picrate anion (Fig. 6). In the case of dihydrazone 5, a transfer of metal ions is also accompanied by the transfer of $\mathrm{Pic}^{-}$anion. A mixedmode extraction involving both the ion-exchange process as well as the metal salt transfer is evidently realized for $\mathbf{5}$. A total extraction percentage of the $\mathrm{Ag}^{+}$and $\mathrm{Cu}^{2+}$ ions recovery by the compound 5 amounts to $136 \%$. These facts indicate apparently that compound $\mathbf{5}$ coordinates the metal ions during extraction by both sides of tetrathiacalix[4]arene platform. 
Thereby, it can be concluded that the synthesized bi-functional derivatives 3-7 are capable of an effective recovering of the $\mathrm{Ag}^{+}$and $\mathrm{Cu}^{2+}$ ions from aqua solutions as well as the $\mathrm{Pb}^{2+}$ ions in the case of the compounds $\mathbf{3 a}$ and $\mathbf{3} \mathbf{b}$. The extraction of metal cations by the compounds $\mathbf{3 - 5}$ is mainly provided due to the binding of the metals by means of carboxylic groups. The preorganization of binding centers on the macrocyclic platform dramatically affects the efficiency and selectivity of the extraction. Moreover, the influence of the substitutes located on opposite side of the macrocycle in 1,3-alternate isomer and nonparticipated in the binding of the metal cations on the extraction properties has been also revealed. This phenomenon is obviously connected with the allosteric effect realized for this class of macrocyclic compounds..$^{22,23,49}$

\section{Conclusions}

In summary, we have reported the synthetic strategy for obtaining of novel bifunctional derivatives of 1,3-alternate tetrathiacalix[4]arene functionalized by carboxylic, ester, hydrazide and hydrazone groups immobilized on opposite sides of the macrocyclic platform. The detailed spectroscopic and structural characteristics as well as receptor properties towards metal ions for the synthesized compounds were established by using X-ray analysis, NMR, IR spectroscopy and liquid-liquid extraction method.

The structure of hydrazide fragments in derivatives $\mathbf{4 a}, \mathbf{4 b}$ and 7 in solution as well as in solid state is characterized by trans-amide conformation which obviously promotes an effective chelate binding of metal ions. The acetylhydrazone fragments in tetrathiacalix[4]arene $\mathbf{5}$ adopt only the $E_{\mathrm{C}=\mathrm{N}}$ configuration. The $E_{\mathrm{C}=\mathrm{N}} / Z_{\mathrm{C}=\mathrm{N}}$ isomerization was not observed for this compound even at UV-light irradiation of its $\mathrm{CDCl}_{3}$ solutions. At the same time the acetylhydrazone substitutes are in cis- and trans-amide conformations, that leads to the realization of a large number of spatial forms of dihydrazone 5 and as a consequence to the significant complication of NMR and IR spectra. The presence of carboxylic and hydrazide groups in the compounds $\mathbf{4 a}$ and $\mathbf{4 b}$ predisposed to the hydrogen bond formation does not produce a noticeable amount of associated molecules $(\sim 5 \%)$ in $\mathrm{CDCl}_{3}-\mathrm{CD}_{3} \mathrm{OD}$ solutions.

The solvent extraction experiments have demonstrated that an increase of $\mathrm{pH}$ of the aqueous phase up to $\mathrm{pH} \sim 5-6$ leads to the rise of the extraction yields of the metals recovery by the compounds $\mathbf{3 a}, \mathbf{3} \mathbf{b}, \mathbf{4 a}, \mathbf{4} \mathbf{b}, \mathbf{5}$ due to the deprotonation of carboxylic groups. The hydrazide derivative 7 also demonstrates the $\mathrm{pH}$ depending extraction properties caused by the protonation of the nitrogen atoms in acid conditions.

The synthesized bifunctional derivatives 3-7 are capable of an effective recognition at $\mathrm{pH} \sim 5-6$ of the $\mathrm{Ag}^{+}$and $\mathrm{Cu}^{2+}$ ions from aqua solutions as well as the $\mathrm{Pb}^{2+}$ ions in the case of the compounds $3 \mathbf{a}$ and $\mathbf{3 b}$. A nature of the binding centers and their preorganization on macrocyclic platform dramatically affect the efficiency and selectivity of the extraction. The extraction ability of dicarbonic acids $\mathbf{3 a}$ and $\mathbf{3 b}$ is significantly higher than for monomeric counterpart 8. The extraction efficiency goes up after removing tert-butyl groups from the upper rim of 1,3- alternate tetrathiacalix[4] arene platform on going from $3 \mathbf{a}$ to $\mathbf{3 b}$. A replacement of ester groups by the hydrazide and pyridinyl hydrazone ones (compounds $\mathbf{4 a}, \mathbf{b}$ and 5) leads to the more selective recovery of $\mathrm{Ag}^{+}$and $\mathrm{Cu}^{2+}$ ions. In the case of dihydrazone 5, a mixed-mode extraction is realized which involves both the ion-exchange process as well as the metal salt transfer.

Thus, we can conclude that the developed synthetic strategy can be successfully applied for the preparing a wide range of bifunctional tetrathiacalix[4]arene derivatives capable of exhibiting excellent receptor properties.

\section{Experimental section}

\subsection{General remarks}

All chemicals were used as commercially received without further purification. $\mathrm{CHCl}_{3}$ and DMF were distilled over $\mathrm{P}_{2} \mathrm{O}_{5}$. THF was purified by distillation over $\mathrm{KOH}$ and sodium. $\mathrm{CDCl}_{3}$ (99.8\% isotopic purity) and $\mathrm{DMSO}^{-\mathrm{d}_{6}}$ (99.5\% isotopic purity) from Aldrich were used for NMR spectroscopy.

Microanalyses of $\mathrm{C}, \mathrm{H}$, and $\mathrm{N}$ were carried out with use of the CHN-3 analyser. Melting points of compounds were measured using a Boetius hotstage apparatus. The purity of the compounds was monitored by TLC. IR absorption spectra were recorded on a Vector-22 Bruker FT-IR spectrophotometer with the resolution of $4 \mathrm{~cm}^{-1}$ as Nujol emulsions and $\mathrm{KBr}$ pellets of compounds. Mass spectra (MALDI) were detected on a Finnigan MALDI-TOF Dynamo mass spectrometer. NMR experiments were performed on a Bruker AVANCE-600 spectrometer at $303 \mathrm{~K}$ equipped with a $5 \mathrm{~mm}$ broadband probehead working at 600.13 $\mathrm{MHz}$ in ${ }^{1} \mathrm{H}$ and $150.864 \mathrm{MHz}$ in ${ }^{13} \mathrm{C}$ experiments. Chemical shifts in ${ }^{1} \mathrm{H}$ and ${ }^{13} \mathrm{C}$ spectra (Table 2) were reported relative to the solvent as internal standard $\left(\mathrm{CDCl}_{3} \delta\left({ }^{1} \mathrm{H}\right)=7.27 \mathrm{ppm}, \delta\left({ }^{13} \mathrm{C}\right)\right.$ $=77.2 \mathrm{ppm}$; DMSO $\left.\delta\left({ }^{1} \mathrm{H}\right)=2.50 \mathrm{ppm}, \delta\left({ }^{13} \mathrm{C}\right)=39.5 \mathrm{ppm}\right)$. Assignment was accomplished by means of $2 \mathrm{D}{ }^{1} \mathrm{H}^{-13} \mathrm{C}$ HSQC and $2 \mathrm{D}{ }^{1} \mathrm{H}^{-13} \mathrm{C}$ HMBC methods. The pulse programs of the HSQC, HMBC, FT-PGSE and NOESY experiments were taken from Bruker software library. The Fourier transform pulsedgradient spin-echo (FT-PGSE) experiments ${ }^{\mathbf{5 0}}$ were performed by BPP-STE-LED (bipolar pulse pair-stimulated echo-longitudinal eddy current delay) sequence. ${ }^{51}$

\subsection{Synthesis}

The synthetic routes and the structural formulae of the investigated compounds are shown in Fig. 1. The parent tetrathiacalix[4]arenes $\mathbf{1 a}^{\mathbf{5 2}}$ and $\mathbf{1 b}^{\mathbf{5 3}}$ as well as the tetrathiacalix[4] arenyloxyacetic acid ethyl esters in 1,3-alternate conformation $\mathbf{2} \mathbf{a}^{\mathbf{2 1}}$ and $\mathbf{2} \mathbf{b}^{\mathbf{2 2}}$ were prepared according to the literature methods. The dicarbonic acids $\mathbf{3} \mathbf{a}$ and $\mathbf{3} \mathbf{b}$ were obtained by the selective hydrolysis of tetrathiacalix[4] arene tetraesters $\mathbf{2 a}$ and $\mathbf{2 b}$ in the presence of an excess of $\mathrm{Cs}_{2} \mathrm{CO}_{3}$ as described by us earlier. ${ }^{24}{ }^{1} \mathrm{H}$, ${ }^{13} \mathrm{C}$ NMR and IR data of the synthesized compounds are presented in Tables 1-3

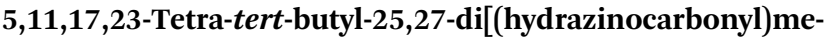
thoxy]-26,28-di[(hydroxycarbonyl)methoxy]-2,8,14,20-tetrathiacalix[4]arene (1,3-alternate 4a). To the solution of 1,3-alternate isomer of $p$-tert-butyltetrathiacalix[4]arene $3 \mathbf{a}(1.0 \mathrm{~g} ; 1 \mathrm{mmol})$ in 
the mixture of THF (15 ml) and $\mathrm{MeOH}(15 \mathrm{ml})$, an excess of $\mathrm{NH}_{2}-\mathrm{NH}_{2} \cdot \mathrm{H}_{2} \mathrm{O}(98 \%, 0.98 \mathrm{ml} ; 32 \mathrm{mmol})$ was added under stirring. The reaction mixture was heated at $65{ }^{\circ} \mathrm{C}$ for 2 days. Then the solvent was removed with using of vacuum distillation at $80{ }^{\circ} \mathrm{C}$ and solid remainder was suspended in $\mathrm{H}_{2} \mathrm{O}(20$ $\mathrm{ml})$. The acidity of the solution was kept by the concentrated $\mathrm{HCl}(0.3-0.6 \mathrm{ml})$ to reach $\mathrm{pH} \sim 5$. The matured precipitate was filtrated and washed with water to a neutral $\mathrm{pH}$. After drying the precipitate under reduced pressure at $90{ }^{\circ} \mathrm{C}$, the target product 4a was obtained as a white powder. Yield: $0.90 \mathrm{~g}(92 \%)$. Mp $272{ }^{\circ} \mathrm{C}$ (decomp.). Anal. Calcd for $\mathrm{C}_{48} \mathrm{H}_{60} \mathrm{~N}_{4} \mathrm{O}_{10} \mathrm{~S}_{4}$ (981.27): C, 58.75; H, 6.16; S, 13.07; N, 5.71. Found: C, 58.44; H, 6.10; S, 13.36; N, 5.47. Mass spectrum (MALDI-TOF): $m / z:=981[\mathrm{M}+$ $\mathrm{H}]^{+} ; 1003[\mathrm{M}+\mathrm{Na}]^{+} ; 1019[\mathrm{M}+\mathrm{K}]^{+}$.

25,27-Di[(hydrazinocarbonyl)methoxy]-26,28-di[(hydroxycarbonyl)methoxy]-2,8,14,20-tetrathiacalix[4]arene (1,3-alternate 4b). Prepared similar to the procedure for $4 \mathbf{a}$ using tetrathiacalix[4] arene $3 \mathbf{b}(1.0 \mathrm{~g} ; 1.3 \mathrm{mmol})$ and an excess of $\mathrm{NH}_{2}-\mathrm{NH}_{2} \cdot \mathrm{H}_{2} \mathrm{O}(98 \% ; 1.3 \mathrm{ml} ; 42 \mathrm{mmol})$. The target product $4 \mathbf{b}$ was obtained as a white powder. Yield: $0.84 \mathrm{~g}(85 \%)$. Mp $287{ }^{\circ} \mathrm{C}$ (decomp.). Anal. Calcd for $\mathrm{C}_{32} \mathrm{H}_{28} \mathrm{~N}_{4} \mathrm{O}_{10} \mathrm{~S}_{4}$ (756.85): C, 50.78; H, 3.73; S, 16.95; N, 7.4. Found: C, 50.45; H, 3.48; S, 16.57; N, 7.75. Mass spectrum (MALDI-TOF): $m / z:=757[\mathrm{M}+\mathrm{H}]^{+} ; 779[\mathrm{M}+$ $\mathrm{Na}]^{+} ; 795[\mathrm{M}+\mathrm{K}]^{+}$.

5,11,17,23-Tetra-tert-butyl-25,27-di[((2-pyridinylmethylidene)hydrazinocarbonyl)-methoxy]-[(hydrazinocarbonyl)methoxy]26,28-di[(hydroxycarbonyl)methoxy]-2,8,14,20-tetrathiacalix[4]arene (1,3-alternate 5). To the solution of 1,3-alternate isomer 4a $(0.49 \mathrm{~g} ; 0.5 \mathrm{mmol})$ in the mixture of EtOH $(12 \mathrm{ml})$ and DMF $(12 \mathrm{ml})$, an excess of the picolinaldehyde $(0.28 \mathrm{ml}, 3 \mathrm{mmol})$ was added under stirring. The reaction mixture was heated at $80{ }^{\circ} \mathrm{C}$ for $36 \mathrm{~h}$. The solid formed was filtered off and washed by EtOH. The product 5 was obtained as a white powder. Yield: $0.31 \mathrm{~g}$ (53\%). Mp $198{ }^{\circ} \mathrm{C}$. Anal. Calcd for $\mathrm{C}_{60} \mathrm{H}_{66} \mathrm{~N}_{6} \mathrm{O}_{10} \mathrm{~S}_{4}$ (1159.46): C, 62.15; H, 5.74; S, 11.06; N, 7.25. Found: C, 62.25; H, 5.48.; S, 11.37; N, 7.45. Mass spectrum (MALDI-TOF): $m / z:=1159[\mathrm{M}+$ $\mathrm{H}]^{+} ; 1181[\mathrm{M}+\mathrm{Na}]^{+}$.

25,27-Di[(chlorocarbonyl)methoxy]-26,28-di[(hydroxycarbonyl)methoxy]-2,8,14,20-tetrathiacalix[4] arene (1,3-alternate 6). To the diester-dicarbonic acide $3 \mathbf{b}(1.25 \mathrm{~g}, 1.2 \mathrm{mmol})$, a fresh distilled $\mathrm{SOCl}_{2}(10 \mathrm{ml}, 138 \mathrm{mmol})$ was added. The reaction mixture was refluxed for $2 \mathrm{~h}$ under argon atmosphere. Then the solvent was removed from the reaction mixture by distillation. The residue was drying under vacuum at $80{ }^{\circ} \mathrm{C}$. The target product 6 was obtained as a yellowish powder. Yield: $1.2 \mathrm{~g}(96 \%)$. Mp 148-152 ${ }^{\circ} \mathrm{C}$.

25,27-Di[(hydrazinocarbonyl)methoxy]-26,28-di[(ethoxycarbonyl)methoxy]-2,8,14,20-tetrathiacalix[4]arene (1,3-alternate 7). A mixture of absolute THF $(40 \mathrm{ml})$ and $\mathrm{NH}_{2}-\mathrm{NH}_{2}(0.75 \mathrm{ml}$, $24 \mathrm{mmol}$ ) previously distilled on $\mathrm{KOH}$ was cooled down to $0{ }^{\circ} \mathrm{C}$ under vigorous stirring. Then dichloroanhydride $6(0.82 \mathrm{~g}, 1$ $\mathrm{mmol}$ ) in $20 \mathrm{ml}$ of THF was added dropwise during $0.5 \mathrm{~h}$ and the reaction mixture was vigorously stirred at $0{ }^{\circ} \mathrm{C}$ during 1.5 h. Thereafter, a solvent was removed under reduced pressure at $40{ }^{\circ} \mathrm{C}$. The obtained residue has been treated by $\mathrm{H}_{2} \mathrm{O}(50 \mathrm{ml})$ and extracted with dichloromethane $(50 \mathrm{ml})$. The organic layer was separated, washed twice with water and dried with $\mathrm{MgSO}_{4}$. After filtration, the solvent was removed by distillation. The residue was drying under vacuum at $80{ }^{\circ} \mathrm{C}$. Yield: $0.59 \mathrm{~g}(72 \%)$. Mp 169-171 ${ }^{\circ} \mathrm{C}$. Anal. Calcd for $\mathrm{C}_{36} \mathrm{H}_{36} \mathrm{~N}_{4} \mathrm{O}_{10} \mathrm{~S}_{4}$ (812.95): C, 53.19; H, 4.46; S, 15.78; N, 6.89. Found: C, 53.33; H, 4.27.; S, 15.34; N, 6.77. Mass spectrum (MALDI-TOF): $m / z:=813[\mathrm{M}+$ $\mathrm{H}]^{+} ; 835[\mathrm{M}+\mathrm{Na}]^{+} ; 851[\mathrm{M}+\mathrm{K}]^{+}$.

4-tert-Butyl-phenoxyacetic acid (8). To 4-tert-butyl-phenoxyacetic acid ethyl ester ${ }^{54}(2.13 \mathrm{~g}, 9 \mathrm{mmol})$ the solution of $\mathrm{KOH}$ $(0.76 \mathrm{~g}, 13.5 \mathrm{mmol})$ in water $(6 \mathrm{ml})$ was added. The reaction mixture was heated at $70{ }^{\circ} \mathrm{C}$ for $0.5 \mathrm{~h}$. After cooling it down to 5$10{ }^{\circ} \mathrm{C}$, the concentrated $37 \% \mathrm{HCl}(2 \mathrm{ml})$ was added under stirring. The resulting mixture was extracted with dichloromethane $(3 \times 5 \mathrm{ml})$. The organic layer was separated and washed twice with $10 \% \mathrm{HCl}(10 \mathrm{ml})$ and water. After drying it over $\mathrm{MgSO}_{4}$, the solvent was removed by distillation. The residue was dried under vacuum at $100{ }^{\circ} \mathrm{C}$. The crude product was recrystallized from hexane $(12 \mathrm{ml})$. Yield: $1.64 \mathrm{~g}$ (87\%). Mp 86-88 ${ }^{\circ} \mathrm{C}$. Anal. calcd for $\mathrm{C}_{12} \mathrm{H}_{16} \mathrm{O}_{3}$ (208.25): C, 69.21; H, 7.74. Found: C, 69.33; H, 7.67.

\subsection{Crystal structure}

The X-ray diffraction data for the crystals of $\mathbf{4 a}, \mathbf{4 a} \cdot \mathbf{2} \mathbf{N H}_{\mathbf{2}} \mathbf{N H}_{2}$, $\mathbf{4 b} \cdot \mathbf{N H}_{2} \mathbf{N H}_{2}, \mathbf{5}$ and $\mathbf{7}$ were collected on a Bruker Smart Apex II CCD diffractometer in the $\omega$ and $\varphi$-scan modes using graphite monochromated Mo $\mathrm{K}_{\alpha}(\lambda=0.71073 \AA)$ radiation at $150(2) \mathrm{K}$ (4a) and at 296(2) K for other samples. Data were corrected for the absorption effect using SADABS program. ${ }^{55}$ The structures were solved by direct method and refined by the full matrix least-squares using SHELXTL ${ }^{56}$ and WinGX ${ }^{57}$ programs. All nonhydrogen atoms were refined anisotropically. The hydrogen atoms were inserted at calculated positions and refined as riding atoms except the hydrogen atoms on solvents molecules, hydroxyl groups and amino groups, which were located from difference maps and refined using a riding model. Data collections: images were indexed, integrates, and scaled using the APEX2 (ref. 58) data reduction package. Analysis of the intermolecular interactions was performed using the program PLATON. ${ }^{59}$ Mercury program package ${ }^{60}$ was used for figures preparation.

Crystallographic data (excluding structure factors) for the structure $4 a, 4 a \cdot 2 \mathbf{N H}_{2} \mathbf{N H}_{2}, \mathbf{4 b} \cdot \mathbf{N H}_{2} \mathbf{N H}_{2}, \mathbf{5}$ and 7 have been deposited in the Cambridge Crystallographic Data Centre as supplementary publication numbers CCDC 1437363-1437367 respectively.

Crystallographic data for $4 a \cdot \mathrm{C}_{48} \mathrm{H}_{60} \mathrm{~N}_{4} \mathrm{O}_{10} \mathrm{~S}_{4} \cdot \mathrm{C}_{2} \mathrm{H}_{6} \mathrm{OS}$, colorless plate, $0.25 \times 0.14 \times 0.07 \mathrm{~mm}^{3}, M=1059.36$, monoclinic, $a=13.163(5) \AA, b=29.199(11) \AA, c=15.137(5) \AA, \beta=91.473(5)^{\circ}$, $V=5816(4) \AA^{3}, T=150(2) \mathrm{K}$, space group $P 2_{1} / n, Z=4, \mu\left(\mathrm{Mo} \mathrm{K}_{\alpha}\right)$ $=0.255 \mathrm{~mm}^{-1}, \rho_{\text {calc }}=1.210 \mathrm{~g} \mathrm{~cm}^{-3}, F(000)=2248,67104$ reflections measured, 15532 independent reflections $\left(R_{\mathrm{int}}=\right.$ 0.1253), 797 parameters, 447 restraints. Final indices: $R_{1}=$ $0.1075, \mathrm{w} R_{2}=0.2694$ (4474 reflections with $I>2 \sigma_{\mathrm{I}}$ ), $R_{1}=0.2629$ (all data), $\mathrm{w} R_{2}=0.3323$ (all data), GoF $=0.875$, largest differ-

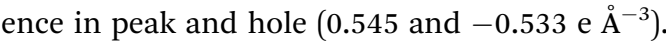

Crystallographic data for $4 \mathrm{a} \cdot 2 \mathbf{N H}_{2} \mathbf{N H}_{2} \cdot \mathrm{C}_{48} \mathrm{H}_{60} \mathrm{~N}_{4} \mathrm{O}_{10} \mathrm{~S}_{4}-$ $\cdot 2 \mathrm{~N}_{2} \mathrm{H}_{4}$, colorless block, $0.41 \times 0.32 \times 0.13 \mathrm{~mm}^{3}, M=1045.34$, monoclinic, $T=296(2) \mathrm{K}, a=35.723(8) \AA$, $b=13.121(3) \AA$, $c=$ 
$25.422(6) \AA, \beta=108.104(3)^{\circ}, V=11326(4) \AA^{3}$, space group $C 2 / c$, $Z=8, \mu\left(\right.$ Mo K $\left._{\alpha}\right)=0.226 \mathrm{~mm}^{-1}, \rho_{\text {calc }}=1.226 \mathrm{~g} \mathrm{~cm}^{-3}, F(000)=$ 4448, 13275 independent reflections, 3458 reflections with $I>$ $2 \sigma_{\mathrm{I}}, 650$ parameters, 121 restraints. Final indices: $R_{1}=0.0952(I$ $\left.>2 \sigma_{\mathrm{I}}\right), \mathrm{w} R_{2}=0.2080\left(\mathrm{I}>2 \sigma_{\mathrm{I}}\right), R_{1}=0.2839$ (all data), $\mathrm{w} R_{2}=0.2684$ (all data), GoF (goodness-of-fit on $F^{2}$ ) $=0.763$, largest difference

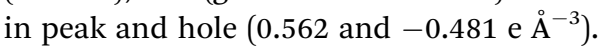

Crystallographic data for $4 \mathbf{b} \cdot \mathbf{N H}_{2} \mathbf{N H}_{2} \cdot \mathrm{C}_{32} \mathrm{H}_{28} \mathrm{~N}_{4} \mathrm{O}_{10} \mathrm{~S}_{4} \cdot \mathrm{N}_{2}$ $\mathrm{H}_{4} \cdot 4 \mathrm{H}_{2} \mathrm{O}$, colorless block, $0.439 \times 0.387 \times 0.246 \mathrm{~mm}^{3}, M=$ 860.94, monoclinic, $T=296(2) \mathrm{K}, a=10.3996(8) \AA, \quad b=$ 16.7027(13) $\mathrm{A}, c=21.9306(18) \AA, \beta=90.2490(10)^{\circ}, V=3809.3(5)$ $\AA^{3}$, space group $P 2_{1} / c, Z=4, \mu\left(\right.$ Mo $\left.K_{\alpha}\right)=0.325 \mathrm{~mm}^{-1}, \rho_{\text {calc }}=$ $1.501 \mathrm{~g} \mathrm{~cm}^{-3}, F(000)=1800,41221$ reflections measured, 9032 independent reflections $\left(R_{\text {int }}=0.0261\right), 7845$ reflections with $I>$ $2 \sigma_{\mathrm{I}}, 522$ parameters, 38 restraints. Final indices: $R_{1}=0.0589(I>$ $\left.2 \sigma_{\mathrm{I}}\right), \mathrm{w} R_{2}=0.1455\left(I>2 \sigma_{\mathrm{I}}\right), R_{1}=0.0669$ (all data), $\mathrm{w} R_{2}=0.1503$ (all data), $\mathrm{GoF}=1.110$, largest difference in peak and hole

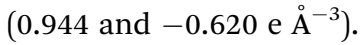

Crystallographic data for 5. $\mathrm{C}_{60} \mathrm{H}_{66} \mathrm{~N}_{6} \mathrm{O}_{10} \mathrm{~S}_{4} \cdot \mathrm{CH}_{3} \mathrm{OH}$, colorless block, $0.109 \times 0.083 \times 0.037 \mathrm{~mm}^{3}, M=1191.47$, triclinic, $T$ $=296(2) \mathrm{K}, a=13.783(13) \AA, b=15.091(14) \AA, c=17.68(2) \AA$, $\alpha=71.891(12)^{\circ}, \beta=85.063(18)^{\circ}, \gamma=69.735(12)^{\circ}, V=3278(6)$ $\AA^{3}$, space group $P \overline{1}, Z=2, \mu\left(\right.$ Mo K $\left._{\alpha}\right)=0.204 \mathrm{~mm}^{-1}, \rho_{\text {calc }}=1.207$ $\mathrm{g} \mathrm{cm}{ }^{-3}, F(000)=1260,39008$ reflections measured, 16924 independent reflections $\left(R_{\text {int }}=0.2261\right), 3408$ reflections with $I>$ $2 \sigma_{\mathrm{I}}, 752$ parameters, 690 restraints. Final indices: $R_{1}=0.1530(I$ $\left.>2 \sigma_{\mathrm{I}}\right), \mathrm{w} R_{2}=0.4178\left(I>2 \sigma_{\mathrm{I}}\right), R_{1}=0.3498$ (all data), $\mathrm{w} R_{2}=0.4690$ (all data), GoF $=0.897$, largest difference in peak and hole (0.692 and -0.483 e $\left.\AA^{-3}\right)$.

Crystallographic data for $7 . \mathrm{C}_{36} \mathrm{H}_{36} \mathrm{~N}_{4} \mathrm{O}_{10} \mathrm{~S}_{4}$, colorless plate, $0.43 \times 0.25 \times 0.08 \mathrm{~mm}^{3}, M=812.93$, monoclinic, $T=296(2) \mathrm{K}$, $a=9.9936(9) \AA, b=18.4615(15) \AA, c=20.6801(17) \AA, \beta=$ 94.046(5) ${ }^{\circ}, V=3805.9(6) \AA^{3}$, space group $P 2_{1} / c, Z=4, \mu\left(\right.$ Mo $\left._{\alpha}\right)$ $=0.312 \mathrm{~mm}^{-1}, \rho_{\text {calc }}=1.419 \mathrm{~g} \mathrm{~cm}^{-3}, F(000)=1696,47387$ reflections measured, 9433 independent reflections $\left(R_{\text {int }}=\right.$ 0.0689), 4234 reflections with $I>2 \sigma_{\mathrm{I}}, 618$ parameters, 354 restraints. Final indices: $R_{1}=0.0606\left(I>2 \sigma_{\mathrm{I}}\right), \mathrm{w} R_{2}=0.1482(I>$ $\left.2 \sigma_{\mathrm{I}}\right), R_{1}=0.1632$ (all data), $\mathrm{w} R_{2}=0.1905$ (all data), $\mathrm{GoF}=1.010$,

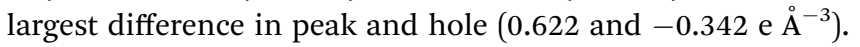

\subsection{Competitive extraction of metal cations}

The $\mathrm{CHCl}_{3}$ was saturated with $\mathrm{H}_{2} \mathrm{O}$ to prevent volume changes during the extraction. Aqueous solutions $(10 \mathrm{ml})$ containing metal salts $\left(\mathrm{NaNO}_{3} ; \mathrm{Ca}\left(\mathrm{NO}_{3}\right)_{2} \cdot 4 \mathrm{H}_{2} \mathrm{O}, \quad \mathrm{Co}\left(\mathrm{NO}_{3}\right)_{2} \cdot 6 \mathrm{H}_{2} \mathrm{O}\right.$, $\mathrm{Ni}\left(\mathrm{NO}_{3}\right)_{2} \cdot 6 \mathrm{H}_{2} \mathrm{O}, \quad \mathrm{Cu}_{2}\left(\mathrm{CH}_{3} \mathrm{COO}\right)_{4} \cdot 2 \mathrm{H}_{2} \mathrm{O}, \quad \mathrm{Zn}\left(\mathrm{NO}_{3}\right)_{2} \cdot 4 \mathrm{H}_{2} \mathrm{O}$, $\mathrm{Pb}\left(\mathrm{NO}_{3}\right)_{2}, \mathrm{AgNO}_{3}$ and $\left.\mathrm{Cd}\left(\mathrm{CH}_{3} \mathrm{COO}\right)_{2} \cdot 2 \mathrm{H}_{2} \mathrm{O}\right)$ were prepared with the concentration for each metal ion $1 \times 10^{-4} \mathrm{M}$. To adjust $\mathrm{pH}$ of the solutions a tris(hydroxymethyl)aminomethane (Tris) and $\mathrm{HNO}_{3}$ were added arbitrarily. The equal volumes of the aqueous mixture of metal salts and the $\mathrm{CHCl}_{3}$ solution of extractant $\left(C_{\mathrm{L} 3 \mathrm{a}, \mathrm{L} 3 \mathrm{~b}, \mathrm{~L} 4 \mathrm{a}, \mathrm{L} 4 \mathrm{~b}, \mathrm{~L} 5, \mathrm{~L} 7, \mathrm{~L} 8}=2 \times 10^{-4} \mathrm{M}\right)$ were magnetically stirred in a flask. The extraction equilibrium was reached after vigorous stirring for $1.5 \mathrm{~h}$ at $25^{\circ} \mathrm{C}$. Then two phases were allowed to settle for $1 \mathrm{~h}$ and afterwards separated by centrifugation.

The $\mathrm{pH}$ and concentration of metal ions in aqueous phase before and after extraction were measured. The relative concentrations of the cations in the aqueous phase were determined by the applying of atomic absorbance spectrometer AAS $1 \mathrm{~N}$ (Carl Zeiss Jena) with the use of oxidative air-acetylene flame. Quantification was made by referring on a standard solution containing a mixture of salts. Blank experiments without added hosts were carried out under the same experimental conditions. The percentage of extraction was calculated as a ratio $E \%=100 \times\left(C_{0}-C_{1}\right) / C_{0}$, where $C_{0}$ and $C_{1}$ are the initial and equilibrium concentrations of metal ion in the aqueous solution determined before and after extraction, respectively. $E \%$ uncertainties are generally $\leq 2 \%$.

\section{Notes and references}

1 J. W. Steed and J. L. Atwood, Supramolecular Chemistry, Wiley, Chichester, UK, 2000.

2 H. W. Lin, Angew. Chem., 2007, 119, 911-914.

3 L. Prodi, F. Bolletta, M. Montaliti and N. Zaccheroni, Coord. Chem. Rev., 2000, 205, 59-83.

4 V. M. Mirsky and A. K. Yatsimirsky, Artificial Receptors for Chemical Sensors, Wiley-VCH, Weinheim, 2010.

5 G. Yu, C. Han, Z. Zhang, J. Chen, X. Yan, B. Zheng, S. Liu and F. Huang, J. Am. Chem. Soc., 2012, 134, 8711-8717.

6 G. Yu, M. Xue, Z. Zhang, J. Li, C. Han and F. Huang, J. Am. Chem. Soc., 2012, 134, 3248-13251.

7 G. Yu, X. Zhou, Z. Zhang, C. Han, Z. Mao, C. Gao and F. Huang, J. Am. Chem. Soc., 2012, 134, 19489-19497.

8 C. D. Gutsche, Calixarenes: An Introduction, The Royal Society of Chemistry, Cambridge, 2nd edn, 2008.

9 Z. Asfary, V. Böhmer, J. Harrowfield and J. Vicens, Calixarenes 2001, Kluwer Academic Publishers, Dordrecht, The Netherlands, 2001.

10 O. K. Sung and C. N. Kye, Bull. Korean Chem. Soc., 2002, 23, 640-642.

11 K. Manoj, D. Abhimanew and B. Vandana, Tetrahedron, 2009, 65, 7510-7515.

12 X.-I. Ni, H. Tomiyasu, T. Shimizu, C. Pérez-Casas, Z. Xi and T. Yamato, J. Inclusion Phenom. Macrocyclic Chem., 2010, 68, 99-108.

13 J. Mendez-Arroyo, J. Barroso-Flores, A. M. Lifschitz, A. A. Sarjeant, C. L. Stern and C. A. Mirkin, J. Am. Chem. Soc., 2014, 136, 10340-10348.

14 S. N. Podyachev, S. N. Sudakova, V. V. Syakaev, A. K. Galiev, R. R. Shagidullin and A. I. Konovalov, Supramol. Chem., 2008, 20, 479-486.

15 S. N. Podyachev, N. E. Burmakina, S. N. Sudakova, V. V. Syakaev and A. I. Konovalov, Supramol. Chem., 2010, 22, 339-346.

16 F. Botha, J. Budka, V. Eigner, O. Hudeček, L. Vrzal, I. Císařová and P. Lhoták, Tetrahedron, 2014, 70, 477-483.

17 L. Kovbasyuk and R. Krämer, Chem. Rev., 2004, 104, 31613187.

18 S. Patai, The Chemistry of Carboxylic Acids and Esters, London, 1969.

19 S. Patai, The Chemistry of Acid Derivatives, New York, 1979.

20 N. Iki, F. Narumi, T. Fujimoto, N. Morohashi and S. Miyano, J. Chem. Soc., Perkin Trans. 2, 1998, 2745-2750. 
21 P. Lhotak and J. Sykora, Collect. Czech. Chem. Commun., 2000, 65, 757-771.

22 A. Ikeda, Y. Suzuki, M. Yoshimura and S. Shinkai, Tetrahedron, 1998, 54, 2497-2508.

23 J. Budka, P. Lhotak, V. Michlova and I. Stibor, Tetrahedron Lett., 2001, 42, 1583-1586.

24 S. N. Podyachev, S. N. Sudakova, B. M. Gabidullin, V. V. Syakaev, A. T. Gubaidullin, W. Dehaen and A. I. Konovalov, Tetrahedron Lett., 2012, 53, 3135-3139.

25 S. N. Podyachev, V. V. Syakaev, S. N. Sudakova, R. R. Shagidullin, D. V. Osyanina, L. V. Avvakumova, B. I. Buzykin, Sh. K. Latypov, V. D. Habicher and A. I. Konovalov, J. Inclusion Phenom., 2007, 58, 55-61.

26 E. Quinlan, S. E. Matthews and T. Gunnlaugsson, J. Org. Chem., 2007, 72, 7497-7503.

27 M. A. Qazi, Ü. Ocak, M. Ocak, S. Memon and I. B. Solangi, J. Fluoresc., 2013, 23, 575-590.

28 X. Li, S.-L. Gong, W.-P. Yang, Y.-Y. Chen and X.-G. Meng, Tetrahedron, 2008, 64, 6230-6237.

29 N. B. Colthup, L. H. Daly and S. E. Wiberley, Introduction to infrared and Raman spectroscopy, London, Academic Press, 1964.

30 L. J. Bellamy, The IR Spectra of Complex Organic Molecules, London: Methuen, N.-Y, Wiley, 2nd edn, 1958.

31 S. N. Podyachev, N. E. Burmakina, V. V. Syakaev, S. N. Sudakova, R. R. Shagidullin and A. I. Konovalov, Tetrahedron, 2009, 65, 408-417.

32 S. N. Podyachev, B. M. Gabidullin, V. V. Syakaev, S. N. Sudakova, A. T. Gubaidullin, W. D. Habicher and A. I. Konovalov, J. Mol. Struct., 2011, 1001, 125-133.

33 C. Jaime, J. de Mendoza, P. Prados, P. Nieto and C. Sanchez, J. Org. Chem., 1991, 56, 3372-3376.

34 P. Lhotak, Eur. J. Org. Chem., 2004, 1675-1692.

35 V. V. Syakaev, S. N. Podyachev, B. I. Buzykin, S. K. Latypov, V. D. Habicher and A. I. Konovalov, J. Mol. Struct., 2006, 788, 55-62.

36 V. V. Syakaev, S. N. Podyachev, A. T. Gubaidullin, S. N. Sudakova and A. I. Konovalov, J. Mol. Struct., 2008, 885, 111-121.

37 P. Stilbs, Prog. Nucl. Magn. Reson. Spectrosc., 1987, 19, 1-45. 38 Y. Cohen, L. Avram and L. Frish, Angew. Chem., Int. Ed. Engl., 2005, 44, 520-554.

39 T. Brand, E. J. Cabrita and S. Berger, Prog. Nucl. Magn. Reson. Spectrosc., 2005, 46, 159-196.
40 N. T. K. Dung and R. Ludwig, New J. Chem., 1999, 23, 603607.

41 K. Ohto, Y. Fujimoto and K. Inoue, Anal. Chim. Acta, 1999, 387, 61-69.

42 B. B. Adhikari, M. Gurung, H. Kawakita and K. Ohto, Analyst, 2011, 136, 3758-3769.

43 B. B. Adhikari, M. Gurung, A. B. Chetry, H. Kawakita and K. Ohto, RSC Adv., 2013, 3, 25950-25959.

44 B. B. Adhikari, M. Gurung, H. Kawakita and K. Ohto, Solvent Extr. Ion Exch., 2013, 31, 483-498.

45 Z. Asfari, V. Lamare, J. F. Dozol and J. Vicens, Tetrahedron Lett., 1999, 40, 691.

46 B. B. Adhikari, K. Ohto, M. Gurung and H. Kawakita, Tetrahedron Lett., 2010, 51, 3481-3485.

47 R. D. Shannon, Acta Crystallogr., Sect. A: Cryst. Phys., Diffr., Theor. Gen. Crystallogr., 1976, 32, 751-767.

48 Y. Takeda, F. Vögtle and E. Weber, Topics of curr. Chem., Springer, Berlin, 1984, vol. 121, pp. 1-38.

49 Z. Asfari, V. Lamare, J. F. Dozol and J. Vicens, Tetrahedron Lett., 1999, 40, 691-694.

50 W. S. Price, NMR Studies of Translational Motion, University Press, Cambridge, 2009.

51 D. Wu, A. Chen and C. S. Johnson, J. Magn. Reson., 1995, 115, 260-264.

52 H. Kumagai, M. Hasegawa, S. Miyanari, Y. Sugawa, Y. Sato, T. Hori, S. Ueda, H. Kamiyama and S. Miyano, Tetrahedron Lett., 1997, 38, 3971-3972.

53 Y. Higuchi, M. Narita, T. Niimi, N. Ogawa, F. Hamada, H. Kumagai, N. Iki, S. Miyano and C. Kabuto, Tetrahedron, 2000, 56, 4659-4666.

54 A. Yamada, T. Murase, K. Kikukawa, T. Arimura and S. Shinkai, J. Chem. Soc., Perkin Trans. 2, 1991, 5, 793-797.

55 G. M. Sheldrick, SADABS, Program for empirical X-ray absorption correction, Bruker-Nonius, 2004.

56 G. M. Sheldrick, SHELXTL v.6.12, Structure Determination Software Suite, Bruker AXS, Madison, Wisconsin, USA, 2000.

57 L. J. Farrugia, J. Appl. Crystallogr., 1999, 32, 837-838.

58 APEX2 (Version 2.1), SAINTPlus, Data Reduction and Correction Program (Version 7.31A), BrukerAXS Inc., Madison, Wisconsin, USA, 2006.

59 A. L. Spek, J. Appl. Crystallogr., 2003, 36, 7-13.

60 I. J. Bruno, J. C. Cole, P. R. Edgington, M. K. Kessler, C. F. Macrae, P. McCabe, J. Pearson and R. Taylor, Acta Cryst., 2002, 58, 389-397. 